TOMASZ STRYJEK

Warszawa

\title{
FIRST NATION EUROPY ŚRODKOWEJ? HISTORIA I WSPÓŁCZESNOŚĆ RUSI KARPACKIEJ W UJĘCIU PAULA ROBERTA MAGOCSIEGO*
}

\begin{abstract}
Abstrakt: Artykuł recenzyjny zawiera analizę podejścia Paula Roberta Magocsiego do historii i współczesności Rusi Karpackiej w jego pracach na ten temat. Autor rozpatruje sposób opowiadania przez kanadyjskiego historyka o dziejach tego regionu $z$ jednej strony w porównaniu z jego syntezą historii Ukrainy, z drugiej - w odniesieniu do założeń modernizmu i konstruktywizmu w studiach nad narodem i nacjonalizmem.
\end{abstract}

Słowa kluczowe: Ruś Karpacka, Karpatorusini, Rusini Karpaccy, Ukraina, problemy narodowościowe, regionalizm, separatyzm, pogranicze.
Abstract: The review article presents an analysis of Paul Robert Magocsi's approach to the history and present time of Carpathian Rus' evident in his texts on the subject. The author investigates the ways in which the Canadian historian describes the history of the region in comparison with his synthesis of the history of Ukraine on the one hand, and with premises of modernism and constructivism in his studies on nations and nationalism on the other.

Keywords: Carpathian Rus', Carpatho-Rusyns, Carpathian Ruthenians, Ukraine, nationalities problems/studies, regionalism, separatism, borderland.

\section{Historyk z Toronto wobec Rusi Karpackiej, Ukrainy i Kanady}

Przygotowując się do napisania o najnowszej książce Paula Roberta Magocsiego With Their Backs to the Mountains. A History of Carpathian Rus' and Carpatho-Rusyns, przejrzałem różne współczesne monografie i tomy pokonferencyjne poświęcone historii Rusi Karpackiej. We wszystkich, o ile zostały wydane poza Ukrainą,

* Paul Robert Magocsi, With Their Backs to the Mountains. A History of Carpathian Rus' and Carpatho-Rusyns, CEU Press, Budapest-New York 2015, ss. 550. 
występuje on jako współautor albo przynajmniej jego prace są wielokrotnie przywoływane. Ten niestrudzony badacz, nauczyciel akademicki i działacz społeczny inspiruje wielu autorów do namysłu nad tym, w jaki sposób i w jakiej mierze przyczynia się swoją działalnością nie tylko do poznania przeszłości tego kraju, ale także do wytwarzania i podtrzymywania wspólnoty jego mieszkańców nazywanej narodowością karpatorusińską ${ }^{1}$. Do stawiania takich pytań nie skłaniają natomiast jego prace poświęcone innym tematom, m.in. synteza dziejów Ukrainy ${ }^{2}$, studia nad historią i procesami narodotwórczymi w Galicji Wschodniej ${ }^{3}$ czy encyklopedia narodowości współczesnej Kanady ${ }^{4}$. Jego podejście do dziejów Rusi Karpackiej warto zatem rozpatrzyć na szerszym tle, przede wszystkim ujęcia historii Ukrainy.

Na zgłaszanie wątpliwości, czy Rusini Karpaccy są już rzeczywistością społeczną czy nadal jedynie projektem, podobnie jak na przypisywanie mu kierowniczej roli w ich ruchu, Magocsi reaguje krytyką. Dotyczy ona nie tylko tych autorów, którzy są idei karpatorusińskiej z założenia przeciwni i stoją na gruncie przynależności całej słowiańskiej ludności Karpat Wschodnich do narodu ukraińskiego ${ }^{5}$, ale także tych, którzy pozostają na jego argumentację otwarci, jednak stawiają znak zapytania nad perspektywami rozwoju czwartej narodowości Słowian Wschodnich. I tak np. na konferencji organizowanej przez Paula Besta oraz Stanisława Stępnia w Przemyślu w 2006 r. „Does a fourth Rus’ exist?” Magocsi zaczął wystąpienie od odrzucenia tego tytułu. Zaproponował, aby zmienić go na następujący: „The Fourth Rus'. A New Reality in A New Europe”. Przekonywał, iż organizatorzy w pogoni za prowokacją intelektualną podważyli istnienie Rusinów Karpackich, narodowości oficjalnie uznanej w Polsce, Słowacji, Rumunii, Węgrzech, Serbii, Chorwacji i Republice Czeskiej. W ten sposób, jego zdaniem, chcąc nie chcąc, wpisali się w interpretacje z czasów komunistycznych i okazali niezdolni do pogodzenia z rzeczywistością Europy Środkowej po rewolucji 1989 r. ${ }^{6}$

${ }^{1}$ Wielu badaczy wywodzących się z Ukrainy zaznacza swój dystans wobec działalności Autora w ruchu karpatorusińskim, np. Taras Kuzio, A Multi-Vectored Scholar for a Multi-Vectored Era. Paul Robert Magocsi, „Nationalities Papers” 39, 2011, 1, s. 95-104. Wyjątkowe podejście reprezentuje Alexander Motyl. Argumentuje on, iż Magocsi, jak każdy nation-builder, „wytwarza” dwa narody: własny karpatorusiński oraz ten, któremu go przeciwstawia, ukraiński - A. Motyl, The Paradoxes of Paul Robert Magocsi. The case for Rusyns and the logical necessity for Ukrainians, „Nationalities Papers” 39, 2011, 1, s. 105-109.

2 P.R. Magocsi, A History of Ukraine, Toronto-Buffalo-London 1996 (wyd. ukr. P.R. Magočij, Istoriâ Ukraïni, Kiïv 2007).

${ }^{3}$ P.R. Magocsi, Galicia. A Historical Survey and Bibliographic Guide, Toronto-BuffaloLondon 1983; idem, The Roots of Ukrainian Nationalism. Galicia as Ukraine's Piedmont, Toronto-Buffalo 2002.

4 Encyclopedia of Canada's Peoples, red. P.R. Magocsi, Toronto-Buffalo 1999.

${ }^{5}$ Np. O. Myshanych, Political Ruthenianism. A Ukrainian Problem, „The Ukrainian Quarterly" 55, 1999, 3, 1997.

6 P.R. Magocsi, The Fourth Rus'. A New Reality in A New Europe, w: Does A Fourth Rus' Exist? Concerning Cultural Identity in the Carpathian Region, red. P. Best, S. Stepien, Przemysl 2009, s. 11-26. 
Z jednej strony tę szczególną wrażliwość Magocsiego można zrozumieć. Trudno sobie wyobrazić, aby ktokolwiek, kto w tytule konferencji naukowej zapytałby np., czy Węgrzy i Polacy istnieją, nie spotkałby się z taką reakcją. Uznano by to za żart, za próbę zdobycia się na oryginalność, czy za jakąś grę $z$ dekonstruktywizmem - w każdym razie za coś, co nie jest warte więcej niż wzruszenie ramion. Położenie Rusinów Karpackich jest rzeczywiście inne. Ukraina na szczeblu ogólnopaństwowym nie przyznała im statusu narodowości. Stało się to jedynie na Zakarpaciu wskutek decyzji tamtejszej rady obwodowej w marcu 2007 r. ${ }^{7}$ Jednocześnie władze Rosji „przypominają” sobie o swych „uciśnionych” przez Ukrainę „braciach” karpackich za każdym razem, gdy konflikty polityczne i debaty tożsamościowe w tej ostatniej wchodzą w fazę przełomową (1990-1993, 2004-2010, od 2013). Ostatni kryzys polityczny w tej kwestii miał miejsce w 2014 r., gdy rychło po aneksji Krymu i wybuchu wojny w Donbasie Moskwa naciskała na władze w Kijowie, grożąc otwarciem także „trzeciego" i „czwartego” frontu - w Naddniestrzu i właśnie na Zakarpaciu. Taka protekcja Rosji jest dla liderów tej narodowości, zrzeszonych w Światowym Kongresie Rusinów z siedzibą w Preszowie na Słowacji, współpracowników Magocsiego, ostatnią rzeczą, jakiej potrzebują. Toteż władze Kongresu odcinają się od działań, swoją drogą, nielicznych, reprezentantów ruchu karpatorusińskiego z Zakarpacia, którzy głoszą hasła niepodległościowe i korzystają ze wsparcia Rosji czy współpracują z prorosyjskimi separatystami na Ukrainie ${ }^{8}$. Jednak wobec tego,

${ }^{7}$ W sierpniu 2012 r. Rada Najwyższa w Kijowie uwzględniła język rusiński wśród 18 języków „regionalnych i mniejszościowych” na Ukrainie w nowej ustawie o języku urzędowym (dotychczas był nim jedynie ukraiński). Otworzyło to możliwość używania go w administracji obwodu zakarpackiego. Głównym beneficjentem ustawy stała się ludność rosyjskojęzyczna Ukrainy wschodniej i południowej. Język rosyjski wprowadzono jako drugi obok ukraińskiego na około połowie terytorium państwa (dotychczas był tam używany, ale bez podstawy prawnej).

${ }^{8}$ W referendum 1 grudnia 1991 r., za porozumieniem z przewodniczącym Rady Najwyższej w Kijowie Leonidem Krawczukiem (Leonìd Kravčuk), na Zakarpaciu do pytania o niepodległość Ukrainy dodano pytanie o nadanie obwodowi autonomii. Na pierwsze pytanie padło 92 proc. głosów na „tak”, a na drugie 78 proc. Jednak następnie Krawczuk, już jako wybrany tego samego dnia prezydent Ukrainy, głosowanie w drugiej kwestii uznał za nielegalne. Pierwszą próbą ustanowienia niezależności Zakarpacia, zignorowaną przez władze w Kijowie, było powołanie 30 maja 1993 r. Rządu Tymczasowego Republiki Podkarpackiej Rusi, w granicach czechosłowackiej autonomii z lat 1919-1938, pod prezesurą profesora Uniwersytetu w Użhorodzie Iwana Turianyci (Ivan Turânicâ). Natomiast proklamowanie tej republiki w październiku 2008 r. przez II Europejski Kongres Rusinów Podkarpackich pod kierownictwem prawosławnego duchownego z Użhorodu ks. Dymitra Sidora (Dimitrij Sidor) i deputowanego do rady obwodowej Jewhena Żupana (Êvgen Župan), zostało potraktowane bardzo poważnie. W 2012 r. za „zamach na integralność terytorialną i nienaruszalność Ukrainy” sąd w Użhorodzie wymierzył Sidorowi karę trzech lat więzienia w zawieszeniu na dwa lata. Jednym z zarzutów było przyjmowanie funduszy od rosyjskiej fundacji rządowej Russkij Mir (zob. P.R. Magocsi, The heritage of autonomy in Carpathian Rus' and Ukraine's Transcarpathian 
że taka „pomoc” jest im z Moskwy nadal „oferowana”, muszą tym bardziej dbać o to, aby istnienie narodowości karpatorusińskiej było bezdyskusyjne.

$Z$ drugiej strony przywołane wystąpienie Magocsiego pokazuje, iż traktuje on rozwój narodowości karpatorusińskiej jako coś więcej niż przedmiot badań. Najprawdopodobniej w tym właśnie, że podchodzi do tej sprawy z większym zaangażowaniem niż zaangażowanie „,badacza”, , doradcy” i ,adwokata” (a tylko na takie określenia swej roli wobec ruchu się zgadza ${ }^{9}$ ), tkwi źródło odpowiedzi na pytanie, dlaczego sobie pozostawia prawo do publicznego rozważania, na ile Rusini Karpaccy są już rzeczywistością, a na ile pozostają wyobrażeniem, innym badaczom zaś tego odmawia. W każdym razie w ostatnim rozdziale książki With Their Backs to the Mountains całkiem przekonująco dowodzi, że nadal są i jednym, i drugim ${ }^{10}$.

W istocie odnośnie do Rusi Karpackiej działalność Magocsiego ma charakter dwoisty. Łączy on rolę akademickiego eksperta od dziejów Ukrainy oraz regionu karpackiego z rolą budowniczego kulturowych i instytucjonalnych fundamentów ruchu karpatorusińskiego, którą określiłbym jako „przodownictwo narodowe". Sądzę, iż Magocsiego można za Florianem Znanieckim traktować jako przedstawiciela elity, która tworzy kulturę narodowości, syntetyzując wielość kultur regionalnych ${ }^{11}$. W przypadku Rusi Karpackiej są to kultury: Łemków w Polsce, Rusinów (Rusnaków) na słowackiej Preszowszczyźnie, słowiańskiej ludności Zakarpacia oraz rumuńskiego Marmaroszu, potomków migrantów do południowej części Królestwa Węgier z czasów habsburskich zamieszkujących dziś Baczkę w Serbii oraz Syrmię w Chorwacji, w końcu członków diaspory w USA i Kanadzie.

Jego szczególna rola polega na zbudowaniu syntezy dziejów Rusinów Karpackich oraz $\mathrm{w}$ związku $\mathrm{z}$ tym zdefiniowaniu granic ich ojczyzny, co ostatecznie nastąpiło właśnie w przywołanej książce. Już w 1978 r. trzydziestotrzyletni Magocsi założył Carpatho-Rusyn Research Center w USA, organizację, która $\mathrm{w}$ następnej dekadzie zaangażowała się w patronowanie rozwojowi identyfikacji karpatorusińskiej głównie w trzecim, mniej więcej równoczesnym z jego własnym pokoleniem emigrantów. Z kolei w 1991 r. uczestniczył w założeniu wspomnianego Światowego Kongresu Rusinów, w latach 2005-2009 był jego prezesem, a następnie został prezesem honorowym.

Jako badacz, historyk ten ukształtował się na studiach na uniwersytetach Rutgers, Princeton i Harvard. Do grona znawców dziejów Europy Środkowej

region, „Nationalities Papers” 43, 2015, 4, s. 587-588). Jedynym przejawem działalności władz tego „państwa” są konferencje prasowe przebywającego stale w Rosji „premiera” Petra Hećki (Pëtr Gecko), który podnosi kwestię „ludobójstwa” jakoby dokonywanego na Rusinach przez władze Ukrainy.

9 P.R. Magocsi, The Scholar as Nation-Builder, or as Advisor and Advocate. Remarks Delivered by Paul Robert Magocsi (Chair of Ukrainian Studies, University of Toronto) for the Special Panel "Paul Robert Magocsi on the Scholar as a Nation-Builder" at the ASN 2007 World Convention, Columbia University, „Nationalities Papers” 36, 2008, 5, s. 888.

10 P.R. Magocsi, With Their Backs to the Mountains, s. 407-408.

${ }^{11}$ F. Znaniecki, Wspótczesne narody, Warszawa 1990. 
i Wschodniej wszedł opublikowawszy w 1978 r. pracę doktorską na temat procesu narodotwórczego na Rusi Podkarpackiej (w granicach Węgier do $1918 \mathrm{r}$. i Czechosłowacji 1919-1939) w latach 1848-1948. Zakończył ją konkluzją, iż do chwili jej wydania, rywalizację na Rusi Karpackiej trzech orientacji narodowych: ukraińskiej, rosyjskiej i rusińskiej, wygrała ta pierwsza wskutek bliskości kulturowej między jej ludnością a ludnością Galicji Wschodniej, skuteczniejszego przywództwa w okresie ich względnie otwartej rywalizacji do 1945 r., a po tej dacie oddziaływania polityki tożsamościowej władz sowieckich ${ }^{12}$. Publikacją tą wywołał duże zainteresowanie w środowisku imigrantów z Karpat Wschodnich. Dwa lata później otrzymał katedrę wykładowcy historii oraz nauk politycznych na Uniwersytecie w Toronto w Kanadzie oraz funkcję kierownika tamtejszych Ukrainian Studies, które zachował do dziś. Wyrazem uznania, jakie zdobył w historiografii północnoamerykańskiej, było przyznanie mu członkostwa w Academy of Humanities of the Royal Society of Canada w 1996 r.

Co do kwestii, kiedy narody powstały i w jaki sposób powstają, Magocsi opowiada się po stronie modernistów i konstruktywistów. Jeszcze wyraźniej występuje publicznie jako zwolennik przyznania jednostce prawa wyboru identyfikacji i swobodnego kształtowania przez nią swej tożsamości. Jednak jednocześnie jego późniejsze prace o historii Rusi Karpackiej (i tylko na ten temat) zdradzają przejawy historyzmu i specyficznego kulturalizmu. Ewolucja poglądów Autora w tym kierunku bierze swój początek $\mathrm{w}$ drugiej połowie lat osiemdziesiątych, gdy w związku z kryzysem komunizmu okazało się, że poczucie odrębnej tożsamości w stosunku do narodu ukraińskiego wśród mieszkańców tego kraju nie zanikło całkiem nie tylko w Czechosłowacji (którą od 1968 r. Magocsi odwiedzał wielokrotnie), ale także na Ukrainie i w Polsce ${ }^{13}$. Historyzmem nazywam tu nie tylko przekonanie, iż przeszłość ma duży wpływ na teraźniejszość, ale także traktowanie historii Rusi Karpackiej jako zobowiązania moralnego dla współczesnych jej mieszkańców. Z kolei wprowadzając termin kulturalizm, nie mam na myśli metodologii wspomnianego Znanieckiego, lecz coś znacznie prostszego: uznanie, iż odrębna karpatorusińska jednostka kulturowa zawiązała się już w średniowieczu oraz absolutyzowanie znaczenia kultury i tradycji w narracji historycznej w perspektywie „długiego trwania”. Nie chcę przez to powiedzieć,

12 P.R. Magocsi, The Shaping of a National Identity. Subcarpathian Rus', 1848-1948, Cambridge Mass.-London 1978, s. 272-275.

${ }^{13}$ Ten kierunek zmian pokazał Jacek Nowak, który zbadał treść artykułów publikowanych na łamach periodyku pod redakcją Magocsiego „Carpatho-Rusyn American” (1978-1997). Karpatorusiński dyskurs tożsamościowy z udziałem czytelników z kraju był rozwijany na łamach tego pisma od jego założenia, ale z początku - podobnie jak praca doktorska Magocsiego - dotyczył jedynie ziem wchodzących w skład dawnych Węgier. W 1987 r. w związku z sygnałami ożywienia działalności Łemków w Polsce redakcja pisma - twierdzi Nowak - „włączyła” ich do wspólnoty Rusinów Karpackich. W ten sposób powstał zarys terytorialny Rusi Karpackiej, który występuje w kolejnych pracach Autora - J. Nowak, Zaginiony świat? Nazywają ich Łemkami, Kraków 2000, s. 189192. Zob. też E. Michna, Łemkowie. Grupa etniczna czy naród?, Kraków 1995, s. 117-123. 
iż Autor przeszedł do obozu perennialistów czy prymordialistów. Jednak sądzę, iż w With Their Backs to the Mountains opowiada on o historii Rusinów Karpackich w taki sposób, że reprezentuje modernizm i konstruktywizm już bardziej deklaratywnie niż faktycznie ${ }^{14}$.

We wstępie wypada jeszcze nadmienić, iż wszystkie prace Magocsiego są oparte na pewnym teoretycznym rozróżnieniu. Argumentując potrzebą rozjaśnienia sytuacji, w której w języku angielskim terminy nation i nationality bywają ze sobą utożsamiane, postuluje on, aby pod pierwszym z nich rozumieć wszystkich obywateli danego państwa, niezależnie od ich językowych i kulturowych osobliwości. Natomiast drugi z nich powinien być, jego zdaniem, stosowany wobec grupy ludzi, którzy mają jedną lub parę wspólnych cech: odrębne terytorium (mogą mieć też, ale niekoniecznie, odrębną państwowość), język, tradycję historyczną, religię, stosunki społeczne i cechy kultury etnicznej (cechy obiektywne narodowości). Z kolei różnica między narodowością a grupą etniczną, która także według Magocsiego charakteryzuje się posiadaniem jednej lub więcej wymienionych cech, zasadza się na tym, że członkowie tej pierwszej są świadomi swej odmienności jako grupy od innych narodowości i grup etnicznych i chcą do niej należeć (cecha subiektywna narodowości) ${ }^{15}$.

W rzeczywistości - argumentuje Magocsi - większość współczesnych państw jest wielonarodowościowa, zatem nieporozumieniem terminologicznym jest stosowanie w naukach humanistycznych koncepcji mniejszości narodowych, która ma charakter prawny. W istocie istnieją wyłącznie narodowości, których poszczególne wspólnoty terytorialne, mniejsze skupiska czy pojedynczy przedstawiciele żyją w jednym lub - o wiele częściej - w wielu państwach. Koncepcja mniejszości narodowych wyniknęła zdaniem autora z dążenia do unifikacji narodowej państw, czyli narzucania identyfikacji z narodem tytularnym ogółowi ich mieszkańców, czego wzorem w historii Europy XIX i XX w. stała się Republika Francuska. Gdyby ta polityka się generalnie powiodła, nastąpiłoby zniszczenie narodowości, a współcześnie istniałyby wyłącznie wewnętrznie zunifikowane narody wytworzone przez państwa. Jednak - argumentuje Magocsi - ponieważ w większości przypadków unifikacja narodowa zakończyła się fiaskiem, po $1918 \mathrm{r}$. dla narodowości niepaństwowych stworzono prawną koncepcję mniejszości narodowych, a po 1945 r. w Europie Zachodniej zbudowano jeszcze międzynarodowy system ich ochrony ${ }^{16}$.

Zatem - twierdzi Magocsi - Rusini Karpaccy są dziś jedynie narodowością, inaczej niż Ukraińcy, Polacy, Słowacy i Rumuni będący jednocześnie narodowościami dominującymi liczebnie w państwach obejmujących dziś obszar

${ }^{14}$ Znaczenie i nazwy dwu par paradygmatów w studiach nad narodem i nacjonalizmem (perennializm - modernizm i prymordializm - konstruktywizm) czerpię z A.D. Smith, Nationalism and Modernism. A critical survey of recent theories of nations and nationalism, London-New York 1998.

15 P.R. Magočij, Istoriâ Ukraïni, s. 308.

16 P.R. Magocsi, On the Writing of the History of Peoples and States, „Canadian Slavonic Papers" 46, 2004, 1-2, s. 121-129, 138-139. 
Rusi Karpackiej oraz źródłem nazw ich narodów tytularnych. To rozróżnienie dodajmy - jest bliskie realiom współczesnej Kanady, gdzie polityka wielokulturowości ma rangę konstytucyjną, z jedną wszelako różnicą terminologiczną. W tamtej rzeczywistości stanowiący przytłaczającą większość potomkowie białych imigrantów - anglofoni i frankofoni - są traktowani jako dwie narodowości, które wraz z narodowościami autochtonicznymi (First Nations) i wywodzącymi się od nie-białych imigrantów na równych prawach tworzą naród Kanadyjczyków. Ta koncepcja narodu ma charakter ściśle polityczny. Wprowadzenie tego rozróżnienia przez Magocsiego do syntezy dziejów Ukrainy i Rusi Karpackiej przeważnie nie znajduje zrozumienia u historyków ukraińskich. Zgodnie z nim w XIX w. wszystkie wspólnoty na tym obszarze (nawet Węgrzy i Polacy w okresach, w których nie mieli odrębności politycznej) były narodowościami. Narodami, z reguły o charakterze wielonarodowościowym, stawały się wraz z wywalczeniem sobie państwa - z reguły w 1918 i 1991 r.

Magocsi argumentuje, iż Rusinom Karpackim należy się na Ukrainie status odrębnej narodowości, zatem - można wnioskować - przyznanie im go miałoby związek z polityką jedynie taki, że ich kultura zostałaby objęta ochroną prawną, język wszedłby do szkół publicznych, a organizacje otrzymały dofinansowanie państwowe ${ }^{17}$. Jednak przeciwnicy uznania tej narodowości pytają, czy taki status „wystarczy” na stałe liderom ruchu karpatorusińskiego, innymi słowy - czy kiedyś nie uznają oni, że ich wspólnota dojrzała do tego, aby stać się narodem. Ich obawy żywią się tym, że o ile w Kanadzie i USA w ostatnim stuleciu nie było przypadku próby secesji terytorialnej ze strony First Nations, o tyle historia najnowsza Europy Środkowej i Wschodniej w nie obfitowała. Z uwagi na dominującą tu kulturową koncepcję narodu oraz wykorzystywanie konfliktów narodowościowych przez sąsiadów jedynie w okresie po rozpadzie ZSRR i Jugosławii byliśmy świadkami secesji: Naddniestrza, Abchazji, Południowej Osetii, Czarnogóry, Kosowa, Krymu i próby secesji tzw. Noworosji (obecnie już tylko Donbasu).

Zdeklarowany modernizm i poszanowanie dla praw jednostki wiążą Magocsiego z podejściami przeważającymi współcześnie w ramach międzynarodowego pola studiów nad narodem i nacjonalizmem, z kolei historyzm i kulturalizm zbliżają go do autorów większości syntez dziejów narodów i państw Europy Środkowej i Wschodniej piszących o własnych krajach. O ile jego synteza dziejów

17 O konsekwencji Magocsiego w podejściu do Rusinów Karpackich jako jedynie narodowości świadczy m.in. to, że nie kwestionuje on ich sytuacji prawnej w Polsce. Ustawą z 2005 r., po pierwsze, zaliczono ich jedynie do mniejszości etnicznych (wraz z Karaimami, Romami i Tatarami), nie zaś do mniejszości narodowych (czyli narodów mających swe państwa na świecie, np. Ukraińców, Białorusinów czy Żydów). Po drugie, ustawa nazywa ich wyłącznie „Łemkami”, posługując się etnonimem upowszechnionym od początku XX w. Ich prawne uznanie w Polsce nie zakończyło sporu między autonomistami a zwolennikami koncepcji, iż Łemkowie są regionalną ukraińską grupą etniczną - E. Michna, Tożsamość Łemków u progu XXI wieku. Ciągłość i zmiana, „Studia Migracyjne - Przegląd Polonijny" 37, 2011, 4, s. 191-192. 
Ukrainy zbudowana jest tylko w oparciu o te pierwsze koncepty, o tyle w syntezie dziejów Rusi Karpackiej dochodzą do głosu także te drugie. Dlatego książka ta z jednej strony spełnia standardy współczesnej historiografii akademickiej, z drugiej - może odegrać rolę tożsamościotwórczą w stosunku do współczesnych mieszkańców kraju. W drugiej z tych ról może być porównywana z klasycznymi syntezami historii narodów Europy Środkowej Františka Palackiego czy Mychajły Hruszewskiego (Mihajlo Gruševs'kij).

\section{Synteza historii Ukrainy: bez głównego bohatera aż do schyłku XIX w.}

Anglojęzyczna wersja syntezy dziejów Ukrainy była owocem wykładu Magocsiego na ten temat prowadzonego w Toronto od roku akademickiego 1980/1981. Po uzupełnieniach została przetłumaczona na język ukraiński i opublikowana w Kijowie w 2007 r. W zdefiniowaniu jej przedmiotu Autor wyszedł od tzw. terytorialnej koncepcji dziejów Ukrainy, pochodzącej od jego nauczyciela z Harvardu, historyka i turkologa Omeliana Pricaka, ukształtowanej w USA w latach siedemdziesiątych.

Zgodnie z koncepcją terytorialną za przedmiot całościowych syntez historycznych należy uznawać wszystkie wspólnoty, zjawiska czy procesy, które w przeszłości w porządku chronologicznym miały miejsce czy toczyły się na terytoriach współczesnych państw. Synteza historyczna Ukrainy miała zatem być skonstruowana wokół innego niż następujące tematy: 1) dziejów ukraińskiej grupy etnicznej od czasu zasiedlenia przez Słowian; 2) struktur władzy tworzonych kolejno przez jej ludność od czasów prehistorycznych; 3) kształtowania się odrębnej jednostki kulturowej Rusi południowej (Ukrainy) od średniowiecza i 4) powstania w XIX w. ukraińskiej ideologii narodowej oraz nowoczesnej masowej tożsamości narodowej ${ }^{18}$.

18 Podejścia te znalazły wyraz w kolejnych syntezach historii Ukrainy napisanych w XX w. Pierwsze u historyków ze szkoły narodnickiej w drugiej połowie XIX i pierwszych dekadach XX w., głównie Mychajły Hruszewskiego (М. Грушевський) Iсторія України-Руси, t. 1-11, Kyjiw 1991), a drugie u ich polemistów ze szkoły państwowej (derżawnyćka) w okresie międzywojennym (m.in. Wiaczesław Łypynski [В’ячесла́в (Вацлав) Липи́нський], Україна на переломі. Замітки до історії держкавного будівництвва в XVII-ім столітmю, Kyjiw 1920; Stepan Tomasziwski [Степан Томашівський], Історія України. Старинні і середні віки, München 1948). Z kolei trzecie ujęcie występuje u autorki syntezy historii Ukrainy do końca XVIII w. z lat dziewięćdziesiątych ubiegłego stulecia Natalii Jakowenko ([Nataliâ Âkovenko], Historia Ukrainy do 1795 r., Warszawa 2011), czwarte zaś u autorów, którzy inspirowali się esejami Iwana Łysiaka-Rudnyckiego z lat pięćdziesiątych-osiemdziesiątych XX w. (І. Лисяк-Рудницький, Історичні есе, t. 1-2, red. Ф. Сисин, oprac. Я. Грицак, Kyjiw 1994) oraz modernizacyjną teorią powstania narodów, głównie Romana Szporluka i Jarosława Hrycaka (Âroslav Gricak) (J. Hrycak, Historia Ukrainy 1772-1999. Narodziny nowoczesnego narodu, Lublin 2000). 
Pricak zakładał, iż przyjmując na wstępie jakiekolwiek założenia interpretacyjne, autor syntezy wpadłby w pułapkę teleologii. Aby jej uniknąć, należało jego zdaniem bez żadnych preferencji przedstawić całą wiedzę o przeszłości ziem wchodzących w skład współczesnego państwa, rzetelnie informując czytelnika o różnicach $\mathrm{w}$ interpretacji poszczególnych zjawisk i wydarzeń występujących między ich badaczami. Obok interpretacji reprezentowanych przez przedstawicieli czterech wymienionych stanowisk w historiografii ukraińskiej, należało także uwzględnić stanowiska historiografii narodowości współmieszkających z Ukraińcami w przeszłości na terytorium współczesnej Ukrainy, w końcu tych historyków, którzy jej przeszłość badają, ale się z nią w żaden sposób nie identyfikują. Jedynym „momentem teleologicznym” w tym podejściu było wyjście od terytorium współczesnego państwa. Pricak przyjął, że bez tego rodzaju „rzutowania” w przeszłość ram opisywanego przedmiotu, powstałych ostatecznie dopiero w połowie XX w. (w przypadku Ukrainy w 1954 r., gdy do Ukraińskiej Socjalistycznej Republiki Sowieckiej przyłączono Krym), napisanie całościowej historii jakiejkolwiek zbiorowości terytorialnej byłoby niemożliwe ${ }^{19}$.

Synteza dziejów miała być zatem opowieścią o losach wszystkich narodowości, które istniały w przeszłości i istnieją obecnie na terytorium danego państwa: w przypadku Ukrainy nie tylko etnicznych Ukraińców, ale także Rosjan, Polaków, Żydów, Białorusinów, Tatarów, Mołdawian, Węgrów, Rumunów, Bułgarów, Greków i Niemców. Magocsi rzeczywiście przygotował syntezę zgodną z tymi założeniami ${ }^{20}$. Wśród współczesnych opracowań historii tego kraju wyróżnia się ona bezstronnością, co Autor dodatkowo podkreślił we wstępie, zaznaczając, iż została napisana przez cudzoziemca dla cudzoziemców ${ }^{21}$. W przeciwieństwie do autorów syntez historii Ukrainy szkoły narodnickiej i państwowej, Magocsi nie przypisał motywów działania uczestników ukraińskiego ruchu narodowego w XIX i XX w. postaciom z wcześniejszych okresów. Motywy tych ostatnich rozpatrywał w kontekście właściwym dla danej epoki: rywalizacji dynastycznej, konfliktu wyznaniowego, ksenofobii, w końcu interesu stanowego czy ekonomicznego. W konsekwencji jego narracja była daleka od idealizacji takich bohaterów ukraińskiego etosu narodowego jak m.in. Bohdan Chmielnicki czy Iwan Mazepa. Autor często przytaczał interpretacje poszczególnych wydarzeń alternatywne w stosunku do powtarzanych w większości syntez dziejów Ukrainy, wypracowane w historiografii rosyjskiej, polskiej i żydowskiej, np. rzezi Humania przez ruch hajdamacki w 1768 r. Trzeba dodać, że nie przypisywał im równej wartości - z reguły bardziej cenił narrację strony słabszej, a w przypadku

19 Rethinking Ukrainian History, red. I.L. Rudnytsky, J.-P. Himka, Edmonton 1981, s. 233-236.

${ }^{20}$ Okazał się bardziej wierny wskazówkom Pricaka niż inny uczeń tego ostatniego, Orest Subtelny. Jednak to synteza Subtelnego, bliższa ujęciu narodnickiemu i państwowemu, zdobyła po 1991 r. palmę pierwszeństwa wśród ukraińskich nauczycieli i studentów historii (wyd. ukr. O. Subtelny, Ukrajina. Istorija, Kyjiw 1991).

${ }^{21}$ P.R. Magočij, Istoriâ Ukraïni, s. 6. 
prześladowań czy zbrodni - strony reprezentującej ofiary. Stąd w jego ocenie odnośnie do historii XVIII-XX w. przeważnie interpretacje historyków rosyjskich i sowieckich miały mniejszą wiarygodność niż te pochodzące od historyków ukraińskich czy niewywodzących się z Europy Wschodniej. Ale też nigdy nie były odrzucane.

Szczególny walor tej pracy wyraża się we wprowadzeniu do analizy procesów narodotwórczych na Ukrainie w XIX i XX w. perspektywy konfliktu między strukturą wielu lojalności kulturowych i narodowych a strukturą wzajemnie wykluczających się tożsamości narodowych. Autor przyjął, iż w XIX w. ludzi wykształconych na ziemiach Ukrainy - jak w całej Europie na ziemiach wkraczających w epokę modernizacji - przeważnie charakteryzowała tzw. etniczność sytuacyjna (fakultatywna), nie zaś pierwotna (ustalona). Reprezentanci tej pierwszej deklarowali różne tożsamości w różnych fazach swego życia, czy nawet $\mathrm{w}$ różnych codziennych sytuacjach, co wynikało z ich lojalności wobec różnych tradycji, idei i centrów władzy. Lojalności te były skonfigurowane czy zhierarchizowane w sposób właściwy poszczególnym jednostkom czy niewielkim grupom społecznym, a nie dużym zbiorowościom terytorialnym ${ }^{22}$.

Zgodnie z jego ujęciem ruch ukraiński, ugruntowany w oparciu o ideologię kijowskiego Bractwa św. św. Cyryla i Metodego (1846-1847) i twórczość Tarasa Szewczenki (Taras Ševčenko) z połowy XIX w., jako pierwszy na Ukrainie trafił do niższych warstw społecznych z przesłaniem uniwersalnych idei wolnościowych i opowiedział się za uczestnictwem ogółu jej ludności w ekskluzywnej tożsamości narodowej. Członkom ruchu chodziło o taką tożsamość, która oddzieli słowiańskich mieszkańców Ukrainy od innych narodów, szczególnie tych, które długo nią władały (Rosjanie, Polacy), zredukuje poczucie więzi łączącej wyznawców prawosławia całej Europy Wschodniej do wymiaru czysto religijnego, pomijając jego wymiar cywilizacyjny związany z jednocześnie sakralnym i państwowym pojęciem Rusi (uosobionym przez władcę i ukształtowanym pod wpływem tradycji bizantyjskiej), w końcu odrzuci lojalność wobec zewnętrznych ośrodków władzy, z których rządzono ziemiami ukraińskimi w XIX i XX w. ${ }^{23}$

Magocsi przyjął, iż zarówno w części ziem Ukrainy rządzonej przez carat, jak przez Habsburgów (w pierwszym przypadku dopiero od ok. 1900 r., w drugim już od ok. 1860 r.) przed 1917 r. ruch ukraiński wszedł w trzecią - zgodnie ze schematem Miroslava Hrocha - tzw. polityczną fazę procesu odrodzenia narodowego ${ }^{24}$. Oznaczało to, iż osiągnął gotowość do budowy własnego państwa. Gdyby to się wówczas stało - pozwalam sobie tu rozwinąć tok myśli Autora Ukraińcy staliby się narodem w znaczeniu używanym przez niego już w okresie międzywojennym. W takiej sytuacji wskutek jednoznacznej polityki tożsamościowej państwa najprawdopodobniej już wtedy doszłoby na Ukrainie do radykalnego ograniczenia zjawiska wielu lojalności kulturowych i narodowych.

\footnotetext{
${ }^{22}$ Ibidem, s. 309-313.

${ }^{23}$ Ibidem, s. 314-316.

${ }^{24}$ P.R. Magocsi, A History of Ukraine, s. 359-381.
} 
Jednak - wracając do argumentacji Magocsiego - to, że ziemie Ukrainy pozostały aż do 1991 r. pod rządami zewnętrznych ośrodków władzy, przyczyniło się do tego, iż wielu mieszkańców nie musiało podjąć jednoznacznej decyzji co do swej identyfikacji narodowej. Jego zdaniem po 1918 r. na powstałą wcześniej całą gamę konfiguracji lojalnościowych nałożyła się polityka nowych państw, które z jednej strony, w przeciwieństwie do caratu, w jakiejś mierze uwzględniały już istnienie Ukraińców (ale jedynie jako narodowości), z drugiej - dążyły do zintegrowania ogółu swych obywateli. W zmodyfikowanej postaci struktury wielu lojalności przetrwały aż do powstania niepodległego państwa w $1991 \mathrm{r}$. Najbardziej liczną reprezentacją tego zjawiska od lat dwudziestych do lat osiemdziesiątych XX w. byli ludzie identyfikujący się z USRS jako odrębną jednostką terytorialną w ramach ZSRR, a nie Rosją czy niepodległą Ukrainą. W jakiejś mierze ci ludzie o tożsamości ukraińsko-sowieckiej byli następcami tych, którzy w późnym XIX w. przyjęli płynącą z Petersburga ofertę bycia reprezentantami „małorosyjskiej gałęzi” „wielkiego narodu rosyjskiego” (hierarchiczne skonfigurowanie dwu lojalności).

Magocsi nie przedstawił wprost oceny ani tej specyficznej tożsamości, ani USRS jako państwa, w którym ona rozkwitła. Niemniej o tym, iż w jego całościowej ocenie polityki władz sowieckich były zawarte elementy pozytywne, świadczą pośrednio dwa stwierdzenia. Po pierwsze, uznał, że obywatele USRS jako jednostki mieli się przeważnie lepiej niż pod rządami carskimi - i materialnie, i z uwagi na możliwość manifestowania swej nierosyjskiej identyfikacji. Po drugie, wręcz wyraził zadowolenie, iż pod rządami sowieckimi Ukraina pozostała krajem wielu narodowości, gdzie ok. 1/4 obywateli deklarowała identyfikację inną niż ukraińska ${ }^{25}$.

W swej narracji Magocsi potraktował Ukraińców jak narodowość do ok. 1900 r., czyli do momentu „upolitycznienia" ukraińskiego procesu narodotwórczego (w sensie Hrocha) w obu częściach kraju. W związku z tym do tego etapu ukazywał poszczególne okresy w historii Ukrainy w kontekście dziejów państw, których częścią były jej poszczególne ziemie. Odnośnie do XX w. ta narracja stała się bardziej „zintegrowana”, a jej głównym podmiotem stały się ukraińskie partie polityczne, formacje zbrojne i instytucje kulturalne oraz sama USRS.

Główną zaletą podejścia Magocsiego w syntezie dziejów Ukrainy było zwrócenie uwagi na wymiar jednostkowy dziejów oraz na alternatywne w stosunku do ukraińskiego procesy narodotwórcze na jej obszarze w XIX-XX w., które ostatecznie nie zakończyły się powstaniem narodów. Szczególnie wskazanie na długotrwałe pozostawanie rusofilów i starorusinów w rywalizacji z narodowcami ukraińskimi o rząd dusz wśród ludności Galicji Wschodniej do 1918 r. stanowiło istotny wkład tego historyka w badania nad ukraińskim procesem narodotwórczym. Jego praca przyczyniła się do zakwestionowania prymordialistycznych ujęć historii kraju popularnych w historiografii ukraińskiej po $1991 \mathrm{r}$. Jednocześnie nigdy nie należała do najbardziej popularnych. Po rozpoczęciu

${ }^{25}$ Ibidem, s. 663-665. 
przez państwo ustawą z 9 kwietnia 2015 r. polityki całkowitej desowietyzacji przestrzeni publicznej, ambiwalentne podejście Magocsiego do USRS dla niektórych w Kijowie budzi nieufność. Niemniej jego synteza nadal jest dostępna na rynku księgarskim i znajduje się w spisach lektur polecanych studentom na uniwersytetach.

\section{Synteza historii Rusi Karpackiej: mit fundacyjny głównego bohatera}

Natomiast With Their Backs to the Mountains z jednej strony reprezentuje wiele spośród wymienionych zalet syntez dziejów Ukrainy, z drugiej - daje wyraz szczególnemu traktowaniu przez Autora narodowości karpatorusińskiej. Ta moja ocena wynika nie z wzięcia pod uwagę jego pozaakademickiej działalności, lecz z analizy treści i języka samej pracy.

I w niej Magocsi pochyla się nad słabszymi, jednak tym razem ta pozycja jest wyraźnie zajęta przez jedną społeczność: słowiańską ludność Rusi Karpackiej, etniczną bazę współczesnej narodowości. Jej ciężki los miał polegać na tym, że od średniowiecza do współczesności nieprzerwanie podporządkowywano ją zewnętrznym ośrodkom władzy. We wprowadzeniu Autor rysuje analogię między Rusinami Karpackimi a Kurdami z uwagi na podobieństwo górskiego krajobrazu ich ojczyzn, dającego schronienie przed uciskiem, a także ze względu na bezpaństwowość i negatywny wpływ na ich kulturę wywierany przez obce państwa ${ }^{26}$. Przydaje to kwestii karpatorusińskiej znaczenia, ale jako porównanie historyczno-polityczne jest mało przekonujące. Po pierwsze, Kurdowie stanowią w swoim regionie wyjątkowy substrat etniczny, całkiem różny od otaczających ich Arabów, Turków, Ormian i ludów Iranu. W przypadku Rusinów Karpackich granica językowa między nimi a sąsiadami jedynie w przypadku Węgrów i Rumunów była bardzo wyraźna. Po drugie, Kurdowie od 1918 r. pozostają liczącym się na Bliskim Wschodzie uczestnikiem stosunków międzynarodowych, który kilkakrotnie walczył o niezależność, wystawiając bitne siły partyzanckie. Po trzecie, zgodnie z nomenklaturą Autora obecnie w Iraku Kurdowie już są narodem (autonomia terytorialna z jedynie nominalnym zwierzchnictwem Bagdadu), a ich stopień organizacji polityczno-wojskowej w Turcji i Syrii wskazuje na to, że i tu by nim byli, gdyby nie używanie siły przeciw nim przez te państwa. Innymi słowy, charakter ruchu kurdyjskiego i karpatorusińskiego jest zupełnie inny. Porównanie, którego celem było jedynie podkreślenie potrzeby zagwarantowania Rusinom Karpackim prawa do zachowania własnej kultury, kieruje uwagę czytelnika w stronę zbrojnej walki o niepodległość i kwestii integralności terytorialnej Ukrainy, co jest sprzeczne z intencjami samego Autora.

Z kolei w zakończeniu Magocsi pisze z sympatią o działaniach współczesnego kulturowego ruchu karpatorusińskiego. Stwierdza, iż trzecie „odrodzenie

${ }^{26}$ P.R. Magocsi, With Their Backs to the Mountains, s. XVII-XVIII. 
narodowe" na Rusi Karpackiej od 1989 r. ma daleko lepsze warunki do tego niż dwa poprzednie, aby rozwinąć proces narodotwórczy do takiego stadium, iż wyobrażenie ostatecznie stanie się rzeczywistością ${ }^{27}$. Argumentuje, że na jego korzyść działa otwartość granic w ramach Unii Europejskiej oraz rozwój środków komunikacji i łączności, a także obowiązywanie konwencji o ochronie mniejszości Organizacji Bezpieczeństwa i Współpracy w Europie i Rady Europy w państwach regionu, co zapewnia zainteresowanie międzynarodowej opinii publicznej. Autora cieszy to, że w czołówce ruchu znaleźli się reprezentanci kategorii społecznych rzadziej występujący w historii ruchów narodowych w tej części Europy: po pierwsze, młodzi, po drugie, wykształceni, po trzecie, w dużej mierze kobiety. Z tych względów są oni, jego zdaniem, dobrze przygotowani do ról kierowniczych i programowych, w tym do modernizacji kultury karpatorusińskieje ${ }^{28}$.

Moja teza o tożsamościotwórczym aspekcie pracy wynika także z przyjęcia przez Magocsiego takiego wyjaśnienia pochodzenia chrześcijaństwa na Rusi Karpackiej, które z jednej strony ustanawia mit fundacyjny historii tutejszej narodowości, z drugiej - „odcina” ją od Rusi Kijowskiej i Ukrainy. Postępuje on za autorem pierwszej historii kraju, dziewiętnastowiecznym „budzicielem narodowym" Mychajłą Łuczkajem Popem (Myhajlo Lučkaj Pop, Historia Carpato-Ruthenorum, Budae 1843) oraz tradycją biskupstwa mukaczewskiego. Zgodnie z nimi chrystianizację przeprowadzili św. św. Cyryl i Metody, rychło po swym przybyciu z Bizancjum w 863 r., gdy Karpaty Wschodnie znalazły się w zależności od Państwa Wielkomorawskiego. W X w. obrządek słowiański na terytorium nieistniejącego już państwa Mojmiroviciów został zniszczony przez najeźdźców węgierskich lub wyparty przez obrządek łaciński, jednak miał utrzymać się w interesującym nas zakątku Karpat.

Z używaniem w następnych stuleciach języka starocerkiewnosłowiańskiego w liturgii na Rusi Karpackiej Autor wiąże powstanie terminu „Rusini”, którym wobec jej mieszkańców (ludzi „ruskiej wiary”) zaczęli posługiwać się ich zachodni sąsiedzi należący do obrządku katolickiego. Oznacza to, iż Rusini Karpaccy byli pierwszymi Słowianami Wschodnimi, którzy przyjęli chrześcijaństwo (prawie dwa stulecia przed jego ostatecznym rozpadem na zachodnie i wschodnie), czym wyprzedzili Ruś Kijowską o całe stulecie ${ }^{29}$.

${ }^{27}$ W przyjętej przez niego chronologii pierwsze „odrodzenie narodowe” miało miejsce pod rządami Wiednia od Wiosny Ludów do przekształcenia monarchii w dualistyczną (1848-1868), a drugie w okresie przynależności kraju do Czechosłowacji (19191939) - ibidem, s. 408.

${ }^{28}$ Ibidem, s. 409-412.

${ }^{29}$ Ibidem, s. 36-41, 51. Właśnie opowiedzenie się za tą tradycją przez Magocsiego skrytykował kolejny recenzent jego prac, Serhii Plokhy z Harvardu. O ile Plokhy docenił zalety wielokulturowego ujęcia historii Ukrainy przez Magocsiego, o tyle wskazał na to, że odwołując się do założeń multikulturalizmu, jednocześnie angażuje się on w udowodnienie autochtoniczności i odrębności jednej z kultur, które dziś wchodzą w skład tego państwa. Jego zdaniem Autor, dekonstruując prymordialistyczną narrację o dziejach narodu, wprowadza w jej miejsce opartą na tych samych założeniach narrację 
Jednak dociekania początku chrystianizacji i pochodzenia nazwy kraju nie zostały rozstrzygnięte źródłowo. Nie wiadomo, jak daleko na wschód sięgał wpływ Państwa Wielkomorawskiego czy misyjnej działalności Apostołów Słowian. Skądinąd sam Autor twierdzi, iż między przekroczeniem przez Węgrów Karpat około 896 r. a ustanowieniem przez ich władców rzeczywistej kontroli nad Rusią Karpacką we wczesnym XII w. była to ziemia niemal bezludna ${ }^{30}$. Zatem - można na tej podstawie wnioskować - nawet jeśli wcześniej dotarło tu chrześcijaństwo, to ciągłość ośrodków kultu została przerwana. Nie ma pewności, czy ośrodek, któremu przypisuje się bycie siedzibą biskupstwa misyjnego - monastyr św. Mikołaja w Mukaczewie - powstał przed najazdem mongolskim na Węgry w 1242 r., ani czy biskupstwo takie istniało nawet po tym wydarzeniu. Pierwsze pewne informacje o rezydowaniu biskupa w Mukaczewie pochodzą dopiero z XV w.

Magocsi nawiązuje do swego wizerunku modernisty i konstruktywisty, gdy stwierdza, iż przedstawiona przez niego wersja wydarzeń „początkujących” odrębność kulturową Rusi Karpackiej ma charakter hipotetyczny, niemniej przedstawia tylko ją ${ }^{31}$. W dyskusji nad pochodzeniem i początkami kultury Rusinów Karpackich wybiera dla siebie „łatwych” przeciwników, przez co czytelnicy nabierają przekonania, iż dla jego wersji nie ma naukowej alternatywy. I tak Magocsi słusznie wypomina Hruszewskiemu, iż pisząc na początku XX w., zinterpretował źródła niemieckie i austriackie z XI-XII w. w sposób zbyt jednostronny, aby w sporze o narodową przynależność ludności Rusi Karpackiej uzasadnić stanowisko ukraińskie. Mianowicie uczony ten uznał, że wtedy na interesującym nas obszarze istniała Marchia Ruska (Marchia Ruthenorum), podmiot polityczny wyodrębniony w ramach Królestwa Węgier, etnicznie zaś związany z ludnością zamieszkałą na północ od Karpat ${ }^{32}$. Obecnie wielu uczonych ma zasadnicze wątpliwości co do istnienia Marchii, a także co do jej lokalizacji w Karpatach Wschodnich. Jeszcze więcej mitotwórstwa było w drugiej koncepcji przywołanej przez Magocsiego, tym razem autorstwa „patriotycznych" (jak ich nazywa) polityków i historyków karpatorusińskich od XIX w. do współczesności, którzy z kroniki Gesta Hungarorum z XIII w. „,wyprowadzali” postać księcia Laborca (nazwa rzeki dziś we wschodniej Słowacji). Ten władca Rusinów Karpackich, rezydujący jakoby w pobliżu dzisiejszego Użhorodu, miał w końcu IX w. stawić czoła Węgrom, tuż po przekroczeniu przez nich gór na przełęczy Wereckiej (Tucholskiej). Jego śmierć w tym starciu położyła, ich zdaniem, fundamenty pod prawo współczesnych Rusinów Karpackich do politycznego samostanowienia ${ }^{33}$.

Kwestionując uwikłane w kontekst polityczny interpretacje historyków prymordialistów z obu stron sporu o przynależność narodową ludności Rusi

o dziejach jednej z narodowości - S. Plokhy, Between History and Nation. Paul Robert Magocsi and the Rewriting of Ukrainian History, "Nationalities Papers” 39, 2011, 1, s. 117-124.

${ }^{30}$ P.R. Magocsi, With Their Backs to the Mountains, s. 54-55.

31 Ibidem, s. 26.

32 Ibidem, s. 55.

33 Ibidem, s. 45. 
Karpackiej, Magocsi wzmacnia swoją wiarygodność. Jednak jednocześnie nie mierzy się z argumentacją współczesnych badaczy ukraińskich, którzy zajmują się migracjami rusińskimi przez Karpaty w średniowieczu. Wprawdzie do niedawna historiografia ukraińska miała tu niewiele do powiedzenia, jednak w ostatnich latach Myrosław Wołoszczuk (Miroslav Voloŝuk) z Podkarpackiego Uniwersytetu im. Wasyla Stefanyka z Iwanofrankiwska opublikował kilka artykułów i monografię (podobnie jak synteza Magocsiego ukazała się w 2014 r.) na ten temat w oparciu o dokumenty nadań ziemi i godności „Rusinom” w Królestwie Węgierskim za panowania Arpadów oraz Andegawenów. Ich duża skala zaskakuje, tym bardziej że nazwy rusińskie w miejscach ich osiedlania się występowały nie tylko na Rusi Karpackiej, ale w całym państwie. Czasem pochodzenia beneficjentów nie można ustalić, niemniej wiele wskazuje na to, że przeważnie byli oni przybyszami z ziemi halickiej czy innych części Rusi. Wołoszczuk wiąże przeniesienie terminu „Ruś” przez góry z ruchem wynikłym w XII-XIV w. z ucieczek przed konsekwencjami walk o tron w księstwie halickim (następnie halicko-wołyńskim) i próbami objęcia go przez członków węgierskiej dynastii Arpadów, co było efektem raz to wojen, raz to umów i związków matrymonialnych między tymi ostatnimi a Rościsławowiczami i Romanowiczami. Odrzuca pogląd, iż termin ten funkcjonował na południe od Karpat przed końcem XI w. ${ }^{34}$

Ustalenia tego historyka nie rozwiązują kwestii pochodzenia głównej części ludności Rusi Karpackiej w średniowieczu, bowiem źródła pozwalają wnioskować o przybyciu zza Karpat w XII-XIV w. jedynie niektórych przedstawicieli elity społecznej. Niemniej, pisząc syntezę dziejów zbiorowości zgodnie z założeniami koncepcji terytorialnej, czyli z uwzględnieniem konkurencyjnych interpretacji naukowych, należało je przedstawić. Tym bardziej że sam Magocsi nie jest mediewistą i dokumentów, na które się powołuje Wołoszczuk, raczej nie miał okazji studiować. W całej recenzowanej pracy kwestii podniesionej przez tego historyka ukraińskiego dotyczy tylko zwięzły akapit bez odniesień źródłowych, w którym Autor stwierdza, iż królowie węgierscy sprowadzali wojowników z Rusi Kijowskiej w charakterze gwardii przybocznej, a następnie pozwalali się im osiedlać, czym tłumaczy się występowanie do dziś na Słowacji czy Węgrzech toponimów pochodzenia rusińskiego ${ }^{35}$.

\section{Jakie są granice Rusi Karpackiej?}

Definiując terytorium Rusi Karpackiej, Autor, podobnie jak w przypadku historii Ukrainy, nawiązuje do koncepcji historii terytorialnej, jednak wobec braku współczesnego państwa opiera się na innych przesłankach. Przekonuje, że za

${ }^{34}$ Zob.jego krytykę zwolenników wcześniejszego pochodzenia Rusi Karpackiej, w tym Magocsiego - М. Волощук, „Русь” в Угорському Королівстві (XI - друга половина XIV cm.). Суспільно-політична роль, майнові стосункі, міграціï, Ivano-Frankivs'k 2014, s. 92-111.

35 P.R. Magocsi, With Their Backs to the Mountains, s. 56. 
granice Rusi Karpackiej należy przyjąć zwarte terytorium, na którym Rusini Karpaccy stanowili przynajmniej 50 proc. ludności według spisów z lat 1900, 1910 i 1921, a następnie przedstawić wszystko, co się na nim wydarzyło wcześniej i później ${ }^{36}$. Trzeba przypomnieć, iż między drugim a trzecim spisem mieszkańcy kraju wzięli udział w I wojnie światowej oraz w latach 1918-1919 w podziale terytorium tej części Austro-Węgier między Polskę, Czechosłowację i Rumunię. Ich ówczesne działania i postawy polityczne także należy uwzględnić w ocenie ówczesnego etapu rozwoju identyfikacji z narodowością karpatorusińską.

W ujęciu Magocsiego terytorium Rusi Karpackiej rozciąga się na przestrzeni $375 \mathrm{~km}$ od środkowego Popradu w granicach Słowacji i Polski do rzeki Ruskova (dopływu Vişeu, a następnie północnej Cisy) w Rumunii, w większości po południowej stronie głównego grzbietu Karpat, a po północnej - na obszarze Łemkowszczyzny w Beskidzie Niskim i Bieszczadach Zachodnich. Granice Rusi Karpackiej wyznaczył Magocsi w trzech czwartych długości zgodnie z linią podziału między kulturą ludności wschodniosłowiańskiej zamieszkującej góry i pogórza, a kulturami ludności romańskiej (Rumuni) i ugrofińskiej (Węgrzy) na południu oraz ludności zachodniosłowiańskiej na południowym zachodzie (Słowacy) i północy (Polacy), w obu ostatnich przypadkach z reguły katolickiej. Odnośnie do pozostałej, około jednej czwartej jej granic, położonych na północnym wschodzie, Autor przyjął nie zasadę różnic etnicznych (język ukraiński i język Rusinów wykazują duże podobieństwa i są zaliczane do grupy języków wschodniosłowiańskich) i wyznaniowych (tutejsza ludność, tak jak ludność Ukrainy, jest wyznania prawosławnego lub greckokatolickiego), lecz wododziału między zlewiskami Dniestru i Dunaju biegnącego głównym grzbietem gór od przełęczy Użockiej po źródła najbardziej wschodnich dopływów górnej Cisy.

Oznacza to, iż w zakres Rusi Karpackiej u Magocsiego nie wchodzą północno-wschodnie stoki gór zamieszkałe przez Bojków w Bieszczadach Wschodnich i Gorganach oraz Hucułów w Czarnohorze. Włączenie Łemków oraz niewłączenie Bojków i Hucułów uzasadnia on większą intensywnością kontaktów utrzymywanych w przeszłości między pierwszymi z nich a słowackimi Rusinami niż drugimi i trzecimi a ludnością południowych stoków gór od Użhorodu po Jasynię. Różnicę tę tłumaczy dostępnością komunikacyjną: na Łemkowszczyźnie przełęcze karpackie sięgają wysokości jedynie 500-700 m n.p.m., podczas gdy dalej na wschodzie dochodzą do poziomu 800-1100 m n.p.m. ${ }^{37}$ Wydaje się, że argument o większej wzajemnej izolacji ludności zamieszkującej po obu stronach głównego grzbietu gór w Karpatach Wschodnich niż w Beskidzie Niskim oddaje stan faktyczny, ale tylko do powstania nowoczesnych środków komunikacji w późnym XIX w.

Przyjęcie jako punktu wyjścia stanu obecnego identyfikacji karpatorusińskiej, tj. danych ze spisów z lat 1991, 2001 (2002) i 2011, Autor odrzuca jako krzywdzące. Takie rozwiązanie nie uwzględnia udziału Łemków w wymianie

\footnotetext{
${ }^{36}$ Ibidem, s. 6.

37 Ibidem, s. 11.
} 
ludności między Polską a USRS w latach 1944-1946 oraz ich deportacji na tzw. ziemie odzyskane w Polsce w akcji „Wisła” w 1947 r., a także asymilacji ludności do narodów państwowych na Ukrainie, Węgrzech, w Czechosłowacji, Polsce i Rumunii w całym XX w. ${ }^{38}$ Argument ten można uznać, aczkolwiek jednocześnie trzeba pamiętać, że w tym stuleciu były także okresy, w których niektóre z tych państw prowadziły politykę wspierającą rozwój odrębnej tożsamości ludności poszczególnych ziem Rusi Karpackiej: w Czechosłowacji w latach 1919-1938 (Podkarpatská Rus), w Polsce w latach 1934-1939 (Administracja Apostolska Łemkowszczyzny) i na Węgrzech w latach 1939-1944 (Kárpátaljai vajdaság). John-Paul Himka, historyk porównujący czynniki narodotwórcze w XIX i XX w. w Galicji Wschodniej i właśnie na Rusi Karpackiej, uważa nawet, że w drugim z tych przypadków to właśnie dopiero działania tych państw w okresie międzywojennym skierowane przeciw ukraińskiemu ruchowi narodowemu stworzyły warunki do powstania „rusynizmu” (karpatorusinizmu) jako odrębnej tożsamości i ruchu politycznego. Wcześniejszy, dodaje Himka, dyskurs miejscowej inteligencji stanowił albo przejaw rusofilizmu (w pokoleniu aktywnym w latach pięćdziesiątych-sześćdziesiątych XIX w., głównie reprezentowanym przez Aleksandra Duchnowycza i Adolfa Dobriańskiego [Oleksandr Duhnovič, Adol'f Dobrâns'kij]), albo wiązał losy ludności ze stopniową madziaryzacją jako efektem modernizacji, z zachowaniem lokalnego „kolorytu” kulturowego, w ramach narodu węgierskiego. Jego zdaniem dyskurs ten wyrażał raczej opóźnienie procesów narodotwórczych w zacofanym regionie, do którego ideologia ukraińska słabo docierała, niż strategię kształtowania odrębnego narodu ${ }^{39}$.

Na gruncie interpretacji Himki istnienia tożsamości karpatorusińskiej przed 1918 r. w ogóle trudno byłoby dowieść. Praca Magocsiego w tej kwestii poszerza wiedzę o procesach narodotwórczych, m.in. wskazując na działalność grupy inteligencji (głównie księży greckokatolickich) kolejnego pokolenia, którzy przed 1914 r. starali się oprzeć projekt tożsamościowy na kulturze miejscowej, a nie kształtować jedynie regionalną odmianę kultury rosyjskiej czy węgierskiej, jednak nie zyskali szerszego audytorium ze względu na zdecydowaną politykę asymilacyjną władz Węgier. Niemniej opisanie ich prób ${ }^{40}$ nie daje podstaw, by twierdzić, iż przed wybuchem I wojny światowej istniała odrębna tożsamość Rusinów Karpackich w wymiarze wykraczającym poza garstkę proboszczów greckokatolickich i redaktorów paru periodyków.

W argumentacji Magocsiego na rzecz zdefiniowania granic Rusi Karpackiej wątpliwości budzi przede wszystkim to, czy wybór przez mieszkańców ,języka ruskiego” jako „mowy potocznej” w spisach w Królestwie Węgier (pięciokrotnie od 1869 do 1910) i Galicji (sześciokrotnie od 1857 do 1910) można traktować jako

38 Ibidem, s. 5.

${ }^{39}$ J.-P. Himka, The Construction of Nationality in Galician Rus'. Icarian Flights in Almost All Directions, w: The Intellectuals and the Articulation of the Nation, red. M.D. Kennedy, R.G. Suny, Ann Arbor 1999, s. 146-150.

40 P.R. Magocsi, With Their Backs to the Mountains, s. 138-140. 
wyraz identyfikacji z narodowością karpatorusińską. Nie idzie o to, że w spisach tych nie pytano o narodowość, a jedynie o wyznanie i właśnie o język, lecz o to, że nie dawano możliwości wyboru między identyfikacją „,ugro-rosyjską”, rosyjską, ukraińską i rusińską („rusyńską”, karpatorusińską) oraz brakiem identyfikacji narodowościowej. I tak w całej Galicji do tej samej „ruskiej” kategorii językowej kwalifikowano wówczas zarówno Łemków, Bojków i Hucułów, jak i wszystkich innych słowiańskich mieszkańców, którzy nie wybrali języka polskiego lub „innego języka słowiańskiego” (chodziło głównie o czeski, jednak udział takich osób nie przekraczał poziomu 0,1 proc. ogółu ludności prowincji), a więc także zdeklarowanych rusofilów czy ukrainofilów ${ }^{41}$. Oczywiście gdyby możliwość wyboru między tymi identyfikacjami wprowadzono, olbrzymia większość ówczesnych mieszkańców wsi karpackich miałaby duży problem. Nawet wśród miejscowej inteligencji wybory między orientacjami narodowościowymi były płynne, a wśród chłopów opowiedzenie się za którąś z nich było bardzo rzadkie. W tej sytuacji do I wojny światowej zgłoszenie języka „ruskiego” w spisie należy traktować czy to jako wyraz autochtonizmu, czy to poczucia przynależności do Rusi w sensie cywilizacji słowiańskiej i wschodniochrześcijańskiej, a na Węgrzech również jako świadectwo oporu wobec ostrego narzucania węgierskiego jako języka w urzędzie, szkole i kościele. Jednak jedynie w pojedynczych przypadkach był to wtedy wyraz świadomości przynależności do odrębnej narodowości jako wspólnoty wyobrażonej.

Z kolei wśród sześciu rad, które powstały na Rusi Karpackiej w ciągu trzech miesięcy od upadku Austro-Węgier, trzy opowiedziały się za zjednoczeniem z Zachodnioukraińską Republiką Ludową/Ukrainą (ZURL): w Komańczy (Łemkowszczyzna Wschodnia), Jasynii (Republika Huculska) i Chuście. Z nich dwie pierwsze można uznać za lokalne i peryferyjne, jednak trzecia miała pewną reprezentatywność dla całej wschodniej części Rusi Karpackiej. Dwie kolejne

${ }^{41}$ Magocsi podaje w pracy wyłącznie dane spisowe z Królestwa Węgier: w $1900 \mathrm{r}$. 424 800, a dziesięć lat później 464300 osób mówiących po rusku (co stanowiło zapewne więcej niż 50 proc. ludności na terenach ich zwartego zamieszkania i zgodnie z przyjętym kryterium pozwala mu wyznaczyć granice ojczyzny Rusinów Karpackich; ibidem, s. 141). Danych z Galicji nie podaje, choć mógłby zsumować liczby ludności deklarującej język ruski w poszczególnych powiatach przy granicy z Węgrami. Tu wyodrębnienie ruskiej ludności Karpat od ich północnych sąsiadów zgodnie z jego metodologią byłoby tak samo łatwe, co po południowej stronie gór, ale tylko w zachodniej części obszaru (na Łemkowszczyźnie). W północnych częściach powiatów od nowosądeckiego do krośnieńskiego mieszkała ludność przeważnie rzymskokatolicka i używająca języka polskiego. Jednak dalej na wschód od powiatu sanockiego do kosowskiego rozróżnienie narodowościowe między Rusinami w Karpatach a Ukraińcami zamieszkującymi na północ od nich na podstawie danych spisowych byłoby już niemożliwe (zob. K. Zamorski, Informator statystyczny do dziejów społeczno-gospodarczych Galicji. Ludność Galicji w latach 1857-1910, Kraków-Warszawa 1989, s. 100-105). Ponieważ na tym odcinku Magocsi arbitralnie przyjmuje główny grzbiet gór za granicę Rusi Karpackiej, ostatnią kwestią nie musi sobie zaprzątać głowy. 
rady były za wejściem kraju w skład Czechosłowacji: w Starej Lubowli, reprezentująca Rusinów słowackich (następnie przekształciła się w radę w Preszowie), oraz we Florynce, utworzona przez Łemków z Łemkowszczyzny Zachodniej i Środkowej. Już z tego rozkładu geograficznego widać, że w 1919 r. rysował się podział między wschodem Rusi Karpackiej, optującym raczej za UkrainąRusią, i zachodem preferującym Rosję-Ruś. $W$ drugim przypadku z braku możliwości nawiązania kontaktu z Rosją czy to od razu, czy to w swych kolejnych uchwałach rady już na początku 1919 r. opowiedziały się za wejściem w skład Czechosłowacji. Jej prezydent Tomaš Masaryk deklarował zainteresowanie ideą demokratyzacji Europy Wschodniej w duchu solidarności ogólnosłowiańskiej i udzielił schronienia porewolucyjnym emigrantom politycznym z dawnego Imperium Rosyjskiego. W końcu ostatnia z rad, geograficznie położona w środku, powstała $\mathrm{w}$ największym mieście kraju Użhorodzie, na początku opowiedziała się za pozostaniem kraju na zasadach autonomicznych w ramach „demokratycznych Węgier"42.

Trudno oprzeć się wrażeniu, iż w latach 1918-1919 wystąpiła taka oto prawidłowość: im dalej na zachód od centrum ZURL we Lwowie i Stanisławowie, tym bardziej wierzono, że to państwo ukraińskie jest wynikiem „intrygi habsburskiej" i jako takie nie może się utrzymać oraz tym bardziej wyglądano powrotu Rosjan, którzy od jesieni 1914 do wiosny 1915 r. zajmowali Galicję Wschodnią i Środkową, przenikając przez przełęcze na węgierską stronę Karpat. Odrzucenie orientacji ukraińskiej na Łemkowszczyźnie Zachodniej i Środkowej tłumaczy się w pewnej mierze tym, że przed wejściem armii rosyjskiej niektórzy jej reprezentanci współpracowali z władzami austriackimi przy aresztowaniu i deportacji działaczy rusofilskich do obozu w Thalerhofie w Alpach, gdzie wielu zmarło wskutek złych warunków lub zostało rozstrzelanych. Z kolei po wyparciu armii cara świadczyli przed wiedeńskimi sądami karnymi przeciw oskarżonym o zdradę rusofilom, co zakończyło się orzeczeniem wyroków śmierci ${ }^{43}$. Jednak we wschodniej części Rusi Karpackiej nie było negatywnych doświadczeń z ruchem ukraińskim. Co więcej, względy komunikacyjne przemawiały tu raczej za związaniem się z ZURL niż Czechosłowacją. Od półwiecza istniała transkarpacka linia kolejowa łącząca Użhorod ze Lwowem, a od ćwierćwiecza także połączenie Mukaczewa ze stolicą Galicji i Rachowa ze Stanisławowem ${ }^{44}$. Wskutek tego miasta Galicji były osiągalne szybciej niż Bratysława, nie wspominając już

42 A. Barszczewska, Mołdawscy Csángó a Rusini Karpaccy (1867-1947). Problemy rozwoju tożsamości zbiorowej w Europie Środkowo-Wschodniej w XIX i XX wieku, Warszawa 2012, s. $266-270$.

43 B. Horbal, Działalność polityczna Łemków na Łemkowszczyźnie 1918-1921, Wrocław 1997, s. 33-37. Jednak są badacze, którzy uważają współpracę ukrainofilów z Austriakami w wyniszczeniu rusofilskiej inteligencji Łemkowszczyzny za dyskusyjną - J.J. Bruski, Rusini w Polsce i na Stowacji. Meandry świadomości narodowej, w: Świadomość narodowa w Polsce i Słowacji w XIX i XX wieku, red. S. Bednarek, Wrocław 2003, s. 120 (tam literatura).

${ }^{44}$ Linia Użhorod - Sianki - Sambor - Lwów od 1872 r., linia Mukaczewo - Ławoczne - Stryj - Lwów od 1887 r., a Rachiw - Sianki - Delatyń - Stanisławów od 1895 r. 
o Pradze. Zatem argument Magocsiego o trudności przekraczania przełęczy wschodniokarpackich jako bariery dla rozwoju kontaktów dla okresu od schyłku XIX w. można uchylić.

Węgierskie rozwiązanie autonomiczne przestało być aktualne wraz z upadkiem rządu hr. Mihálygo Károlyiego w Budapeszcie i utworzeniem Węgierskiej Republiki Rad w marcu 1919 r. Wprawdzie komuniści węgierscy pod kierownictwem Béli Kuna w kwietniu-maju podtrzymali ideę autonomii w stosunku do Rusi i Słowacji, to jednak zaraz potem okazało się, że się najprawdopodobniej nie utrzymają, gdyż ententa skierowała przeciw nim wojska francuskie, rumuńskie i czechosłowackie (ostatecznie upadli w sierpniu 1919 r.). Jednocześnie na przełomie kwietnia i maja nastąpiło fiasko prób zdobycia przez ZURL poparcia u mocarstw wersalskich $\mathrm{w}$ konflikcie z Polską: załamały się prowadzone za pośrednictwem wysłanników ententy polsko-ukraińskie negocjacje co do tymczasowego podziału Galicji Wschodniej. Gdyby doszły do skutku, obie strony weszłyby, wraz z Rumunią, w skład koalicji interweniującej w Rosji przeciwko bolszewikom. Jednak obie okazały nieprzejednanie i Polska pozostała jedynym sojusznikiem ententy na północ od Karpat ${ }^{45}$. W tej sytuacji orientacja na ZURL straciła rację bytu, a pójście na układ z Czechosłowacją wydawało się miejscowym liderom jedynym rozwiązaniem, gwarantującym uniknięcie ucisku doświadczanego do 1918 r. ze strony Węgier.

Do takiego wniosku na obradach w dniach 8-16 maja 1919 r. w Użhorodzie doszła Centralna Rusińska Rada Narodowa, utworzona przez reprezentantów rad z tego miasta, Preszowa i Chustu. Do uchwalenia 16 maja decyzji o wejściu Rusi Karpackiej w skład Czechosłowacji na warunkach autonomicznych (ostatecznie bez Łemkowszczyzny, którą ententa przyznała Polsce) zadecydowały dwa czynniki: akcja dyplomatyczna Rusinów w Stanach Zjednoczonych oraz opanowanie terytorium kraju przez armie czechosłowacką i rumuńską. Emigranci, działając pod kierownictwem Hryhorija Żatkowycza (Grigorìj Žatkovič), uzyskali zgodę Masaryka na takie rozwiązanie już 23 października 1918 r. na spotkaniu w Filadelfii. Cieszyło się ono także przychylnością prezydenta USA Thomasa Woodrowa Wilsona. Co więcej, przeprowadzili we własnych środowiskach za oceanem referendum, w którym 66 proc. głosujących opowiedziało się za związkiem Rusi z Czechosłowacją, najprawdopodobniej wyobrażając sobie, iż będzie ona państwem federalnym na wzór USA czy Kanady.

Z kolei wojska rumuńskie już od początku 1919 r. przeciwdziałały rozprzestrzenianiu się Republiki Huculskiej z Jasynii na południe (w styczniu jej oddział, wzmocniony przez ZURL, przejściowo opanował nawet Syhot Marmaroski), a po 16 kwietnia zajęły całą wschodnią część kraju w ramach międzynarodowej operacji przeciw Węgierskiej Republice Rad. Dla zjednoczenia opinii członków rady w Użhorodzie pochodzących z różnych części Rusi Karpackiej przełomowe znaczenie miało wyparcie Węgrów z Użhorodu i Mukaczewa przez

${ }^{45}$ M. Kozłowski, Między Sanem a Zbruczem. Walki o Lwów i Galicję Wschodnią 1918-1919, Kraków 1990. 
armię czechosłowacką w ciągu dwu tygodni poprzedzających obrady. Właśnie $\mathrm{w}$ trakcie trwania obrad rady armia ta na podstawie porozumienia z 9 maja przejmowała od Rumunów kontrolę także nad wschodnią częścią kraju, z wyjątkiem linii kolejowej z Syhotu Marmaroskiego do Jasynii, którą ci ostatni zatrzymali dla zachowania komunikacji z Polską w celu prowadzenia zalecanych przez ententę wspólnych działań przeciw bolszewikom ${ }^{46}$.

Magocsi ukazuje ten międzynarodowy kontekst decyzji podejmowanych przez liderów ludności Rusi Karpackiej, choć nie analizuje dokładnie przebiegu działań wojskowych w kwietniu-maju 1919 r. W konsekwencji w jego wyjaśnieniu motywów decyzji liderów rusińskich czynnik „tożsamościowy” przesłania czynniki „sytuacyjne”. W jego opowieści ostateczne decyzje użhorodzkie stanowią potwierdzenie odrębnej tożsamości i poczucia jedności ludności całej Rusi Karpackiej. Jednak wydaje się, że na tym etapie przemian większość mieszkańców kraju bardziej wiedziała, kim nie chce być, niż kim jest. Nadal żyła w kręgu wielu lojalności kulturowych i narodowych, wstrzymując się przed wyborem jednej, ekskluzywnej tożsamości narodowej. O istnieniu odrębnej narodowości można już wtedy mówić, ale jedynie w przypadku Rusinów pochodzących z karpackiej części Królestwa Węgier w Ameryce. Natomiast w kraju nie było ani jednego ośrodka politycznego, który odciąłby się jednocześnie i od Rosji, i od Ukrainy (nie zrobiła tego nawet pierwsza rada użhorodzka, która występowała w imieniu Ugro-Rusinów). Dominowało przywiązanie do „Rusi”, w końcu niejako w "zastępstwie” wybrano Czechosłowację, której władze nie miały historycznych czy etnicznych roszczeń do terytorium Rusi Karpackiej oraz nie wypowiadały się jednoznacznie ani po stronie Rosji, ani Ukrainy. Stało się tak głównie z powodu poczucia zagrożenia ze strony pozostałych sąsiadów, których nie bez racji podejrzewano o zamiar wymuszenia jednoznacznej identyfikacji czy wprost o dążenia do asymilacji wszystkich narodowości. Tyle tylko, że źródłem tego zagrożenia w każdej części kraju był kto inny: na północy Polacy i/lub Ukraińcy (jedynie dla rusofilów), na południowym zachodzie i w centrum Węgrzy, na wschodzie Rumuni. Obawy przed ich rządami nie wytwarzały jeszcze tożsamości Karpatorusinów jako odrębnej narodowości.

Z kolei w spisach ludności w Czechosłowacji w 1921 i 1930 r. wprowadzono już pytanie o narodowość i kategorię „narodowość ruska”, jednak nadal nie dano możliwości wyboru między orientacją rusińską, ukraińską i rosyjską. Orientacja rusińska, lojalna już wobec Pragi, a nie Budapesztu, na początku lat trzydziestych zyskała przychylność władz Czechosłowacji i ugruntowała podstawy ideologiczne, sformułowane przez reprezentanta ugro-rusinizmu sprzed 1918 r., Awhustyna Sztefana (Avgustin Štefan) oraz greckokatolickiego biskupa mukaczewskiego Aleksandra Stoikę (Aleksandr Stojka) ${ }^{47}$. Autor ocenia, że m.in. dzięki

46 J. Brus, Tahanice o karpatské hřebeny, „Military Revue” 2011, 12, s. 16-19.

${ }^{47}$ J.J. Bruski, Rusini Karpaccy - separatyzm czy przebudzenie narodowe? (Z genezy wczesnego rusinizmu), w: Regionalizm a separatyzm - historia i wspótczesność. Śląs na tle innych obszarów, red. M.W. Wanatowicz, Katowice 1995, s. 169-170. 
tej zmianie tuż przed kryzysem Czechosłowacji w 1938 r. wśród inteligencji siła wpływu orientacji rusińskiej, ukraińskiej i rosyjskiej była względnie równa. Dane spisowe nie dają jednak podstaw do twierdzenia tego samego o całej ludności. Wątpliwości budzi też ich interpretacja przez Magocsiego, który za Ukraińców i Rosjan w ówczesnej Czechosłowacji proponuje uważać jedynie emigrantów z dawnego Imperium Rosyjskiego i Galicji. Szacuje, że na obszarze Rusi Podkarpackiej w latach trzydziestych tych ostatnich było nie więcej niż 3 tys., zatem jego zdaniem mieszkańcy prowincji o narodowości karpatorusińskiej stanowili przytłaczającą większość ${ }^{48}$.

Jednak w przeciwieństwie do okresu przed 1914 r. ludność regionu była już rozbudzona politycznie dzięki przyznaniu powszechnego prawa wyborczego i w większej liczbie alfabetyzowana. O tym, że wraz z inicjacją polityczną niższych warstw orientacja ukraińska rozwijała się szybko już w latach dwudziestych, można wnioskować pośrednio ze stopnia poparcia w wyborach parlamentarnych dla partii komunistycznej, która w kwestii narodowej deklarowała orientację ukraińską ${ }^{49}$. W latach 1938-1939 polityka prowadzona przez premiera prowincji ks. Augustyna Wołoszyna (Avgustin Vološin) - pozostanie w Czechosłowacji jako trzeci ukraiński człon federacji - zyskała stosunkowo największe poparcie mieszkańców (choć z pewnością znacznie mniejsze niż 92,5 proc. głosów, jakie padły na jego partię w wyborach 12 lutego 1939 r. $)^{50}$. Z kolei działania rządu węgierskiego na Rusi Karpackiej w latach 1939-1944 były ukierunkowane przede wszystkim na zatrzymanie wpływów ukraińskich i odwrócenie przemian poprzez rozwijanie projektu ugro-rusińskiego ${ }^{51}$.

Sądzę zatem, że Magocsi zdefiniował granice Rusi Karpackiej na podstawie danych ze zbyt wczesnego etapu kształtowania tożsamości zbiorowej. Zdecydowanie pewniejsze byłoby wykorzystanie danych spisowych z roku 1938 czy 1944, wszakże one nie istnieją. W zależności od przynależności państwowej kraju i polityki władz centralnych wobec niego w okresie międzywojennym

${ }^{48}$ P.R. Magocsi, With Their Backs to the Mountains, s. 222. I w tym wypadku brak u Magocsiego danych z Polski. Tu w spisie z $1921 \mathrm{r}$. dopuszczono wprawdzie pytanie o narodowość, pozwalając na wybór między „Rusin” i „Rosjanin”, ale nadal nie wyodrębniono kategorii „Ukrainiec”. Z kolei w spisie z 1931 r. pytano już tylko o język „ruski” lub „rosyjski”.

${ }^{49} \mathrm{~W}$ wyborach uzupełniających do czechosłowackiego parlamentu na Rusi Podkarpackiej w marcu 1924 r. partia komunistyczna zdobyła pierwsze miejsce (100 tys. głosów, 39,4 proc.)! W tym samym roku na V Kongresie Kominternu uznano ludność kraju za Ukraińców i wezwano tamtejszą partię do walki o zjednoczenie z Ukraińską SRS. W wyborach ogólnopaństwowych w 1929 r. głosów na komunistów padło już jedynie 14,8 proc., ale i tak był to trzeci wynik w tej części kraju.

${ }^{50}$ Nie było to wybory wolne, gdyż inne partie poza Ukraińską Unią Narodową premiera i Deutsche Partei zostały zakazane, a liderów rusofilów wręcz uwięziono J.J. Bruski, Rusini Karpaccy, s. 174.

${ }^{51}$ W ówczesnej oficjalnej nomenklaturze „ugro-rosyjskiego” - A. Barszczewska, op. cit., s. 302-309. 
proces narodotwórczy mógł potoczyć się w kierunku rusińskim (gdyby władze Czechosłowacji rzeczywiście honorowały autonomię przyznaną Rusi Podkarpackiej w 1919 r.) lub ukraińskim (gdyby ZURL przetrwała i opanowała Zakarpacie lub gdyby już wtedy włączono je do USRS, a na początku lat trzydziestych nie było Hołodomoru i Stalin nie odszedł od polityki ukrainizacji). $\mathrm{W}$ porównaniu $\mathrm{z}$ tym warto wskazać na ówczesne zaawansowanie projektu ukraińskiego. Biorąc pod uwagę różnice w rozwoju ideologii, języka literackiego, inteligencji i struktur organizacyjnych oraz skalę uczestnictwa ludności w ruchu, w okres międzywojenny Ukraińcy galicyjscy wkraczali już jako narodowość z aspiracjami do bycia narodem, Rusini Karpaccy zaś byli raczej grupą etniczną, wahającą się między paroma projektami narodowościowymi i usiłującą odnaleźć się w nowoczesnym świecie poprzez dołączenie do państw, które powstały na gruzach Austro-Węgier. W każdym razie teza o istnieniu w pierwszym dwudziestoleciu XX w. narodowości karpatorusińskiej jako zwartej terytorialnie kilkusettysięcznej społeczności wydaje się niewystarczająco ugruntowana.

\section{Ideologia ukraińska na Rusi Karpackiej w XX wieku jako projekt modernizacyjny}

Autor - skądinąd zwolennik przekonania, że narody powstały dopiero w epoce nowoczesności - słabo uwzględnia w pracy modernizację jako podstawową „dźwignię" ideologii narodowych w Europie Środkowej i Wschodniej w drugiej połowie XIX i pierwszej połowie XX w. Z pracy można pośrednio wywnioskować, że tak nieliczna społeczność, składająca się przede wszystkim z ubogiego chłopstwa, stanowiąca mniejszość w miastach i prawie całkiem pozbawiona możliwości kapitałowych, miała bardzo ograniczone szanse wytworzyć i upowszechnić własną ideologię modernizacyjną, jednak nigdzie jednoznacznie to nie zostało napisane. Szkoda, że Autor nie przeprowadził porównania czynników wpływu na ludność Rusi Karpackiej tych ideologii, które docierały do niej „z zewnątrz”. W moim przekonaniu porównanie takie prowadzi do konkluzji, iż najmocniejsze atuty miał ukraiński projekt narodowy. A także do wniosku, że najważniejszą przyczyną niezdobycia przez niego w XX w. przeważającego poparcia w tym kraju było to, że w przeciwieństwie do państw sowieckiego, węgierskiego, polskiego, rumuńskiego i czechosłowackiego, do 1991 r. nie zaowocował powstaniem państwa ukraińskiego, które mogłoby swoją ideologię modernizacyjną wypromować, a tym bardziej wprowadzićs ${ }^{52}$.

${ }^{52}$ Za takie państwo nie można uznać USRS. Nie tylko ze względu na brak suwerenności, ale także z uwagi na to, że ideologia modernizacyjna sowieckiego komunizmu okazała się w latach trzydziestych-sześćdziesiątych zdolna „przeprowadzić” poszczególne kraje świata od gospodarki rolniczej do przemysłowej, ale w następnych dwu dekadach już niezdolna zaadaptować je do gospodarki postprzemysłowej. 
Sądzę, że ze względu na bliskość językową i wyznaniową oraz wymienione cechy gospodarczo-społeczne regionu to właśnie ideologia ukraińska do 1914 r. w wersji reprezentowanej przez Ukraińską Partię Radykalną ${ }^{53}$, w latach dwudziestych przez komunistów, a także w całym okresie międzywojennym przez ugrupowania istniejące w Galicji Wschodniej: od socjaldemokratów po nacjonalistów - miała dla niższych warstw społecznych Rusi Karpackiej największy potencjał atrakcyjności. Dla miejscowej inteligencji w okresie 1868-1918 punktem odniesienia była przede wszystkim kultura węgierska, a dla niewidzących dla siebie perspektyw awansu w ramach Węgier kultura rosyjska. W okresie międzywojennym konkurencję dla tych dwu kultur stanowiła kultura czeska przynoszona na Ruś Podkarpacką przez przysyłanych z Pragi urzędników, nauczycieli i inżynierów. Ona jako pierwsza otworzyła perspektywy modernizacyjne nie tylko przed elitami, jednak jej centrum było zbyt oddalone oraz oddziaływała zbyt krótko, aby związać ze sobą ludność. Najsłabszą siłę przyciągania wśród kultur narodów państwowych wpływających na Ruś Karpacką do 1947 r. miała kultura polska w stosunku do Łemków. W każdym razie wszystkie kultury narodowe, które były obecne w tym kraju przed jego włączeniem do USRS, wywarły wpływ jedynie na elity społeczne. Wydaje się, że najatrakcyjniejszymi konkurentami na tutejszym „rynku idei narodowych” ${ }^{54}$, mającymi ofertę dla chłopstwa, były ukraińskie partie narodowe oraz komuniści, szczególnie w okresie korenizacji i przed kolektywizacją.

Wyzwoleńcza symbolika Kozaczyzny, którą liderzy ukraińskiego ruchu narodowego w Galicji Wschodniej zaczerpnęli z historii Naddnieprza, a także nieprzeciwdziałanie im, a niekiedy nawet sprzyjanie przez rząd austriacki, przyczyniły się do tego, iż w okresie od około 1880 do 1914 r. tożsamość ukraińska zdobyła przewagę wśród mieszkańców tego kraju. Porażkę poniosły tu adresowane do Rusinów polski i rosyjski projekty narodowe, nie rozwinął się też projekt ukształtowania odrębnego narodu obejmującego należących do obrządków wschodnich chrześcijaństwa mieszkańców Austrii (głównie Galicji i Bukowiny) ${ }^{55}$. Stało się tak, pomimo tego, iż z jednej strony zachodnioukraińskie miasta i Cerkiew unicka wiele wycierpiały od Kozaków w XVII w., z drugiej - takie zjawiska historyczne jak istnienie odrębnego księstwa halicko-wołyńskiego w XII-XIV w., przynależność Rusi Czerwonej do Korony Polskiej (a nie do Wielkiego Księstwa Litewskiego) od 1387 do 1569 r., w końcu istnienie Królestwa Galicji i Lodomerii w Cesarstwie Austriackim (a nie Rosyjskim) w latach 1772-1918, złożyły

53 Jeden z inspiratorów powstania partii galicyjskich radykałów w 1890 r. Mychajło Drahomanow (Mihajlo Dragomanov) odwiedzał Ruś Karpacką już w latach 1875-1876 i zwracał uwagę liderom ruchu w Galicji na potrzebę prowadzenia tam pracy oświeceniowej, jednak bez skutku - I. Лисяк-Рудницький, Драгоманов як політичний теоретик, w: idem, Історичні есе, t. 1, s. 333.

${ }^{54}$ Tego określenia odnośnie do rywalizacji w procesach narodotwórczych w XIXXX w. używa sam Autor - P.R. Magocsi, With Their Backs to the Mountains, s. 112-115.

${ }^{55}$ J.-P. Himka, op. cit. 
się na całkiem bogate zasoby symboliczne, być może wystarczające do tego, aby z Rusinów austriackich można było ukształtować naród inny niż Ukraińcy na Naddnieprzu. Jednak liderzy ukraińscy z Galicji uznali te zasoby za niewystarczające do stworzenia silnej wspólnoty politycznej i sięgnęli po symbole historii całej południowej Rusi, doprowadzając ostatecznie do „zwycięstwa” projektu ukraińskiego.

Magocsi nigdzie nie rozważa potencjału atrakcyjności ideologii ukraińskiej, nawet w latach 1938-1939, gdy opowiedziała się za nią znaczna część politycznie aktywnej młodzieży, odrzucającej skoncentrowany głównie na obronie kultury oraz opierający się na negocjacjach z Budapesztem i Pragą sposób uprawiania polityki przez starsze pokolenie. W żadnej ze swoich prac nie poświęcił też więcej uwagi zbadaniu źródeł popularności ruchu komunistycznego na Rusi Karpackiej, ograniczając swe uwagi na ten temat do ogólnego wskazania na biedę, naiwność ideologiczną chłopów i wiarę w to, że ZSRR stanowi kolejne, po Imperium Rosyjskim, wcielenie Świętej Rusi ${ }^{56}$.

O ile w syntezie dziejów Ukrainy Magocsi był przekonany, iż zawarta w projekcie ukraińskim ideologia modernizacyjna oraz symbolika historyczna były wystarczająco atrakcyjne dla ludności Galicji Wschodniej, o tyle w omawianej książce wydaje się zakładać, że jej potencjał był zbyt mały, aby przyciągnąć do siebie także ludność Rusi Karpackiej. Na rzecz takiego przekonania można przywołać argument, iż w procesach narodotwórczych istnieją granice dla skutecznej transmisji symboli historycznych. W tym przypadku oznaczałoby to, że tradycje książąt kijowskich i hetmanów kozackich były zbyt „obce” dla Rusinów po drugiej stronie Karpat. Granice dla skutecznej recepcji mitów historycznych niewątpliwie istnieją, ale nie sądzę, aby w tym przypadku adaptacja do ukraińskości napotkała na jakieś poważne przeszkody. Tym bardziej że rolnicza i uboga Ruś Karpacka miała znacznie słabsze „własne” zasoby symboliczne niż Galicja Wschodnia. Brakowało jej w ogóle tradycji państwowych i wojskowych ${ }^{57}$, a w jej przeszłości liderzy powstań ludowych czy przywódcy obiecujący ludowi poprawę losu „przychodzili z zewnątrz” i dziś należą głównie do węgierskiego kanonu bohaterów narodowych ${ }^{58}$.

${ }^{56}$ P.R. Magocsi, With Their Backs to the Mountains, s. 317-318.

${ }^{57} \mathrm{Na}$ tę słabość ruchu rusińskiego w porównaniu z ukraińskim wskazał już w koń$\mathrm{cu}$ lat siedemdziesiątych Iwan Łysiak-Rudnycki w recenzji pracy Magocsiego The Shaping of a National Identity - I. Лисяк-Рудницький, Карпатська Україна. Народ у пошуках своеї ідентичності, w: idem, Iсторичні есе, t. 1, s. 458-459.

${ }^{58}$ Węgierska część Rusi Karpackiej była objęta powstaniem kuruców Györgyego Dózsy w 1514 r. oraz powstaniem antyhabsburskim ks. Siedmiogrodu Franciszka II Rakoczego (1704-1711), jednak ich główne ośrodki znajdowały się poza nią. Ten i inne deficyty Rusinów, które nie sprzyjały pomyślnemu „ukończeniu” ich procesu narodotwórczego (niska liczebność, słabość inteligencji, brak odrębności wyznaniowej w stosunku do wschodnich sąsiadów, brak jednego standardu języka literackiego) syntetycznie podsumowuje A. Barszczewska (op. cit., s. 335-357). 


\section{of the making of nationalities there is no end ${ }^{59}$, czyli o porównywaniu historii regionów w Europie Środkowej}

Wszystkie te uwagi pod adresem With Their Backs to the Mountains nie moga jednak przekreślić jej zasadniczych walorów. Jak każda praca tego Autora, stanowi ona fundamentalne naukowe kompendium wiedzy o przeszłości kraju, którego dotyczy. Jest napisana językiem przystępnym dla czytelników nieakademickich, a poznanie tematu za jej pośrednictwem ułatwiają 34 mapy, setki odwołań do źródeł oraz obszerny przegląd bibliografii. Na pytanie, czy ta synteza jest bardziej tożsamościotwórcza niż większość współczesnych syntez dziejów narodowych i państwowych w Europie Środkowej i Wschodniej, odpowiedź brzmi: nie. Identyfikowanie się z własnym krajem jest wśród historyków tej części świata nadal na tyle silne, że wielu z nich w ogóle odrzuca koncepcję terytorialną, nie widzi potrzeby dostarczania czytelnikowi informacji o innych punktach widzenia na przeszłość, w końcu uwzględnia w narracji jedynie losy narodów państwowych, a nie również narodowości czy innych społeczności mniejszościowych ${ }^{60}$.

W zakończeniu warto postawić dwa pytania. Czy można napisać syntezę dziejów kraju, który nigdy nie był państwem czy inną odrębną jednostką polityczną, a dziś reprezentuje przejawy własnej tożsamości w taki sposób, aby uniknąć zarzutów o kierowanie się celem tożsamościotwórczym? W jaki sposób aparat pojęciowy i podejście Magocsiego do historii regionu można wykorzystać do badań komparatystycznych? Sądzę, że na pierwsze pytanie odpowiedź jest pozytywna, jednak, stojąc na gruncie koncepcji terytorialnej, trzeba byłoby inaczej niż Autor podejść do zdefiniowania przedmiotu pracy, a w konsekwencji określenia jego granic. Trzeba wyjść także od „końca” dziejów i spojrzeć „wstecz”, ale nie w celu dostrzeżenia początków współczesnych tożsamości, lecz wyodrębnienia wszystkich tych cech gospodarczych, społecznych i kulturowych regionu, które nałożywszy się kolejno na siebie, określiły jego specyfikę. Na Rusi Karpackiej były to w porządku chronologicznym: późne i „rzadkie” skolonizowanie obszaru ze względu na jego górski charakter, w dużej mierze

59 Tytuł rozdziału czerpię z tytułu kolejnej pracy Autora także w dużej mierze poświęconej Rusi Karpackiej - P.R. Magocsi, of the Making of Nationalities There Is No End, t. 1-2, Boulder Col.-New York 1999.

${ }^{60}$ Dlatego nie sądzę, aby właściwych słów użył do krytyki prac Magocsiego o Rusi Karpackiej historyk ukraiński z Uniwersytetu w Użhorodzie, Ernest Gyidel (Ernest Giìdel). O poprzednim jego dziele na ten temat (Encyclopedia of Rusyn History and Culture, red. P.R. Magocsi, I. Pop, Toronto 2002, II wyd. 2005) napisał, iż stanowi przykład „sofistycznego, nienarzucającego się, "zakonspirowanego» sposobu prezentacji całkowicie i w pełni nacjonalistycznej treści w tekstach typu naukowego” („приклад софістикованого, ненав'язливого, «законспірованого» способу презентації цілком і повністю націоналістичного змісту в наукових текстах") - Е. Гийдел, Рутенія über alles, „Україна Модерна” 2007, 12 (1), s. 216. 
pasterski typ gospodarki ukształtowany głównie z udziałem kolonizacji wołoskiej, dominacja chrześcijaństwa wschodniego, poczucie więzi z szerszą wspólnotą cywilizacyjną na Wschodzie, występowanie gwar wschodniosłowiańskich, duży udział ludności napływowej w miastach (głównie Żydzi, Niemcy, Węgrzy), dystans społeczny, językowy i często także wyznaniowy między dworem a wsią, motyw ludowego oporu wobec „panów” wyrażający się w zbójnictwie, w końcu opóźnione uczestnictwo w procesach modernizacyjnych. Wszystkie te zjawiska występowały po obu stronach głównego grzbietu Karpat, nawet jeśli komunikacja między mieszkańcami południowych i północnych ich stoków do schyłku XIX w. była ograniczona. Zatem, moim zdaniem, pisząc syntezę dziejów Rusi Karpackiej, warto spojrzeć na nią jako na region historyczny, do którego należały także północno-wschodnie stoki gór i pogórza od przełęczy Użockiej po źródła Czeremoszu. Jeśli tak byśmy go określili, możliwe stałoby się przesunięcie punktu ciężkości narracji Autora od problematyki odrębności kulturowej i tożsamościowej ku innym zagadnieniom. W skali mikro byłyby to sposoby adaptacji różnych społeczności (góralskich i „nizinnych”) do zmieniających się warunków gospodarczo-społecznych i wstrząsów politycznych, w skali makro zaś - relacje między regionem jako peryferią paru państw środkowoeuropejskich a oddziałującymi na niego „zewnętrznymi” centrami władzy.

Za takim określeniem granic Rusi Karpackiej jako przedmiotu syntezy dziejowej przemawia także to, że stałaby się ona wdzięcznym tematem do badań komparatystycznych. Większość zjawisk charakterystycznych dla Rusi Karpackiej występowała także w całej tej części terytorium Rzeczypospolitej przedrozbiorowej, która wcześniej należała do Rusi Kijowskiej. W późnym XIX i pierwszej połowie XX w. wszystkie społeczności wiejskie na tym obszarze stanęły wobec konieczności wyboru między identyfikacją rosyjską a ukraińską lub białoruską. Szczególna sytuacja Rusi Karpackiej polegała przede wszystkim na trudnej dostępności terytorium położonego w górach i odległego od dużych ośrodków miejskich, co pomagało mieszkańcom wierzyć, iż wyboru identyfikacji narodowej będzie można uniknąć. Jednak warto podkreślić jeszcze raz, że z tego, iż członkowie jakiejś zbiorowości terytorialnej wyróżniali się w XIX-XX w. silniejszym przywiązaniem do lokalnych tradycji, słabszym uczestnictwem w modernizacji i większą niechęcią do „wielkich” terytorialnych projektów tożsamościowych, nie wynika wprost to, że byli odrębną wspólnotą, tym bardziej że podlegali władzy kilku różnych państw.

Myślę też, że w dłuższej perspektywie czasowej konsekwentne rozróżnianie przez Magocsiego narodowości i narodów warto byłoby przenieść na grunt badań komparatystycznych w Europie Środkowej i Wschodniej. Po pierwsze, w zakresie porównań procesów narodotwórczych. Bardzo interesujące byłoby np. porównanie ukraińskiego procesu narodotwórczego w Karpatach Północno-Wschodnich z rumuńskim w Karpatach Południowo-Wschodnich i Południowych. Góry oddzielające Siedmiogród od Wołoszczyzny i Mołdawii są przecież miejscami jeszcze wyższe niż te między Rusią Karpacką a Galicją Wschodnią. Trwałe zjednoczenie polityczne pierwszych trzech z nich w Królestwie Rumunii 
miało miejsce dopiero w 1918 r., jednak bez szczególnych problemów już przed tą datą wśród ludności Siedmiogrodu i Banatu, poza Szeklerami, Sasami i Żydami, przeważyło poczucie przynależności do narodu rumuńskiego. Ich przedstawiciele na zgromadzeniu w Alba Iulia 1 grudnia 1918 r. nie mieli wątpliwości co do swej tożsamości i jednogłośnie przyjęli deklarację zjednoczenia ze „starym” królestwem. Czy czynnikiem decydującym było tylko to, że ludność Siedmiogrodu już od 1861 r. graniczyła z państwem rumuńskim, podczas gdy w Przedlitawii do 1918 r. nawet nie wyodrębniono Galicji Wschodniej jako osobnego kraju monarchii, pozostawiając ją pod rządami polskimi, czy także inne, wcześniejsze oddziaływania i wpływy? W każdym razie zastanawiające jest, dlaczego w Siedmiogrodzie nie powstał projekt tożsamościowy dla narodowości odrębnej względem narodu Rumunów, odpowiadający projektowi tożsamości karpatorusińskiej odrębnej wobec narodu Ukraińców.

Po drugie, w zakresie komparatystyki historii regionów położonych dziś w granicach paru państw i mieszanych narodowościowo. Pod tym względem interesujące analogie nasuwają się między Rusią Karpacką a... Śląskiem. W obu tych krajach między upadkiem komunizmu w latach 1989-1991 a ostatnim spisem ludności z 2011 r. zanotowano spadek identyfikacji z narodem państwowym na korzyść identyfikacji z narodowością regionalną, wcześniej oficjalnie nieuznawaną. W 2012 r., według danych spisowych z poprzedniej dekady, na Ukrainie, Słowacji, w Polsce, Rumunii, Republice Czeskiej, Serbii, Chorwacji, Stanach Zjednoczonych i Kanadzie liczba osób, które wybrały narodowość karpatorusińską, wyniosła łącznie 110 tys. ${ }^{61}$ Relatywnie najmniej Rusinów było na należącym do Ukrainy Zakarpaciu - w 2001 r. jedynie 10 tys. mieszkańców tego obwodu ${ }^{62}$. Najsilniejszy karpatorusinizm był na słowackiej Preszowszczyźnie (55 tys. deklaracji), gdzie ukrainizacja prowadzona przez państwo w latach 1945-1991 była w największym stopniu postrzegana jako narzucona. Z kolei w Polsce jeszcze według spisu z 1988 r. Ślązacy w ogóle nie istnieli, a już w spisie z 2002 r. było ich 173 tys. W następnej dekadzie zanotowali aż pięciokrotny wzrost i w $2011 \mathrm{r}$. wykazali liczbę 847 tys. ${ }^{63}$ Aczkolwiek nadal stanowią mniejszość w swoim kraju, to jednak w powiecie rybnickim sięgnęli już niemal połowy ludności (41,5 proc.).

Chociaż nie wszystkie elementy historycznej analogii między tymi dwoma regionami nawzajem do siebie pasują - wszak Śląsk to część Polski do 1989 r. silnie zmodernizowana, podczas gdy Zakarpacie w USRS odgrywało rolę ubogiego zaplecza rolniczego - to jednak liczba podobieństw jest i tak uderzająca. Należy

${ }^{61}$ P.R. Magocsi, With Their Backs to the Mountains, s. 1.

${ }^{62} \mathrm{Z}$ kolei dwa nieformalne spisy prowadzone przez organizacje rusińskie na Zakarpaciu ok. 2000 r. przyniosły podobne dane: 6 tys. i 22-28 tys. - T. Kuzio, The Rusyn Question in Ukraine. Sorting out Fact from Fiction, „Canadian Review of Studies in Nationalism" 32, 2005, s. 25-26.

${ }^{63}$ Wiązało się to z wprowadzeniem w 2011 r. możliwości wyboru dwu identyfikacji. I tak z 847 tys. jako jedyną zadeklarowało ją 376 tys. (w tym sensie wzrost od 2002 r. był tylko dwukrotny), razem z polską 431 tys., a z inną niż polska 40 tys. 
do nich wielowiekowe położenie na pograniczu trzech państw (Śląsk: Polski, Czech/Austrii oraz Prus/Niemiec; Ruś Karpacka: Węgier/Czechosłowacji, Polski i Rusi/ZSRR/Ukrainy), a w epoce nowoczesności poczucie położenia między „wyżej cywilizowanym”, acz dalszym kulturowo Zachodem (dla Śląska: Niemcami, Austrią, Czechami; dla Rusi Karpackiej: Austrią, Węgrami, Czechosłowacją) oraz „słabiej rozwiniętym”, acz bliższym językowo i wyznaniowo Wschodem (dla Śląska: Polską; dla Rusi Karpackiej: Rusią/Ukrainą). Podobnym zjawiskiem jest współczesna „alergia” na narodowy etos historyczny, który rozwijają państwowe instytucje polityki pamięci w Polsce i na Ukrainie, odwołujące się do heroicznych i martyrologicznych wydarzeń z miejsc oddalonych o setki kilometrów oraz z czasów, gdy żadna część śląska czy Rusi Karpackiej nie należała do tych dwu państw.

Badanie historii regionów pogranicznych zyskałoby na tym, gdybyśmy wszyscy - historycy, politycy i opinia publiczna - w Europie Środkowej i Wschodniej zaakceptowali rozróżnienie Magocsiego na narody i narodowości. Jednocześnie współczesne stosunki międzypaństwowe i międzynarodowościowe zyskałyby na tym, gdyby historycy potrafili zrezygnować z poszukiwania początków współczesnych narodów i narodowości w epoce chrystianizacji i/lub pierwszej kolonizacji albo przynajmniej przestali przypisywać mity etnohistoryczne poszczególnym z nich na zasadzie wyłączności, odmawiając prawa powoływania się na nie także ich sąsiadom. $O$ ile pierwsze z oczekiwań wyrażonych w poprzednim zdaniu wydaje się nadal nierealistyczne, o tyle można żywić ostrożnie nadzieję, że do drugiego powoli dojrzejemy. Prace Magocsiego stanowią przykład historiografii „otwartej” w tej ostatniej kwestii. Wprawdzie przyczyniają się do kulturowej mitologizacji historii Rusi Karpackiej, ale jednak jednocześnie Autor nikomu nie broni przystać do narodowości Rusinów Karpackich, a tym, którzy nie chcą przystać, dzielić ich mity historyczne.

\section{Streszczenie}

Artykuł recenzyjny zawiera analizę podejścia Paula Roberta Magocsiego do historii i współczesności Rusi Karpackiej w jego pracach na ten temat, szczególnie With Their Backs to the Mountains z 2015 r. Autor rozpatruje sposób opowiadania przez kanadyjskiego historyka o dziejach tego regionu z jednej strony w porównaniu $\mathrm{z}$ jego syntezą historii Ukrainy, $\mathrm{z}$ drugiej - $\mathrm{w}$ odniesieniu do założeń modernizmu i konstruktywizmu w studiach nad narodem i nacjonalizmem. Wskazuje te momenty, w których Magocsi mitologizuje wczesne dzieje Rusi Karpackiej. Krytycznie analizuje jego definicję terytorium Rusi Karpackiej, która nie obejmuje północnych stoków Karpat na obszarze należącym obecnie do Ukrainy. Zwraca uwagę na niedocenienie przez Magocsiego potencjału modernizacyjnego ukraińskiego projektu narodowego na Rusi Karpackiej w końcu XIX i pierwszej połowie XX w. Jednocześnie autor uznaje With Their Backs to the Mountains za pierwsze całościowe kompetentne kompendium wiedzy o historii Rusi Karpackiej. Uznaje je za 
dzieło inspirujące w badaniach nad procesami narodotwórczymi w Europie Środkowej oraz w komparatystyce zajmującej się historią regionów „pogranicznych”, mieszanych pod względem narodowościowym.

\section{First Nation of Central Europe? The history and present day of Carpathian Rus' as depicted by Paul Robert Magocsi}

The review article presents an analysis of Paul Robert Magocsi's approach to the history and present time of Carpathian Rus' evident in his texts on the subject, especially in his With Their Backs to the Mountains of 2015. The author investigates the ways in which the Canadian historian describes the history of the region in comparison with his synthesis of the history of Ukraine on the one hand, and with premises of modernism and constructivism in his studies on nations and nationalism on the other. He indicates these points where Magocsi mythologizes the early history of Carpathian Rus'. Next, he critically analyses Magocsi's definition of the territory of Carpathian Rus' which excludes the northern slopes of the Carpathian Mountains now belonging to Ukraine. He points to the fact that Magocsi underestimates the potential for modernization of the Ukrainian national project in Carpathian Rus' at the end of the nineteenth century and the first half of the twentieth century. At the same time he regards the book With Their Backs to the Mountains as the first comprehensive and highly competent compendium on the history of Carpathian Rus'. In his opinion, this is an inspiring book in research on nation-building processes in Central Europe and in comparative studies in the history of "border regions" with mixed nationalities.

Translated by Grażyna Waluga

\section{Bibliografia}

Barszczewska Agnieszka, Mołdawscy Csángó a Rusini Karpaccy (1867-1947). Problemy rozwoju tożsamości zbiorowej w Europie Środkowo-Wschodniej w XIX i XX wieku, Trio, Collegium Civitas, Warszawa 2012.

Brus Jan, Tahanice o karpatské hřebeny, „Military Revue” 2011, 12, s. 16-19.

Bruski Jan J., Rusini Karpaccy - separatyzm czy przebudzenie narodowe? (Z genezy wczesnego rusinizmu), w: Regionalizm a separatyzm - historia $i$ współczesność. Ślask na tle innych obszarów, red. Maria W. Wanatowicz, WUŚ, Katowice 1995, s. 158-179.

Bruski Jan J., Rusini w Polsce i na Stowacji. Meandry świadomości narodowej, w: Świadomość narodowa w Polsce i Stowacji w XIX i XX wieku, red. Stefan Bednarek, Atut, Wrocław 2003, s. 109-129.

Encyclopedia of Canada's Peoples, red. Paul Robert Magocsi, Muliticultural History Society of Ontario, University of Toronto Press, Toronto-Buffalo 1999.

Encyclopedia of Rusyn History and Culture, red. Paul Robert Magocsi, Ivan Pop, Toronto University Press, Toronto 2002. 
Himka John-Paul, The Construction of Nationality in Galician Rus'. Icarian Flights in Almost All Directions, w: The Intellectuals and the Articulation of the Nation, red. Michael D. Kennedy, Ronald Grigor Suny, University of Michigan Press, Ann Arbor 1999, s. 109-169.

Horbal Bogdan, Działalność polityczna Łemków na Łemkowszczyźnie 1918-1921, Arboretum, Wrocław 1997.

Hrycak Jarosław, Historia Ukrainy 1772-1999. Narodziny nowoczesnego narodu, Instytut Europy Środkowo-Wschodniej, Lublin 2000.

Jakowenko Natalia, Historia Ukrainy do 1795 r., PWN, Warszawa 2011.

Kozłowski Maciej, Między Sanem a Zbruczem. Walki o Lwów i Galicję Wschodnia 19181919, Znak, Kraków 1990.

Kuzio Taras, A Multi-Vectored Scholar for a Multi-Vectored Era. Paul Robert Magocsi, „Nationalities Papers” 39, 2011, 1, s. 95-104.

Kuzio Taras, The Rusyn Question in Ukraine. Sorting out Fact from Fiction, „Canadian Review of Studies in Nationalism" 32, 2005, s. 1-15.

Magocsi Paul Robert, A History of Ukraine, University of Toronto Press, Toronto-Buffalo-London 1996 (wyd. ukr. P.R Magočij, Istoriâ Ukraïni, Kiïv 2007).

Magocsi Paul Robert, Galicia. A Historical Survey and Bibliographic Guide, University of Toronto Press, Toronto-Buffalo-London 1983.

Magocsi Paul Robert, of the Making of Nationalities There Is No End, t. 1-2, Columbia University Press, Boulder Col.-New York 1999.

Magocsi Paul Robert, On the Writing of the History of Peoples and States, "Canadian Slavonic Papers" 46, 2004, 1-2, s. 121-140.

Magocsi Paul Robert, The Fourth Rus', A New Reality in A New Europe, w: Does A Fourth Rus' Exist? Concerning Cultural Identity in the Carpathian Region, red. Paul Best, Stanislaw Stepien, Carpathian Institute, Higganum CT, South-Eastern Research Institute, Przemysl 2009, s. 11-26.

Magocsi Paul Robert, The heritage of autonomy in Carpathian Rus' and Ukraine's Transcarpathian region, „Nationalities Papers” 43, 2015, 4, s. 577-594.

Magocsi Paul Robert, The Roots of Ukrainian Nationalism. Galicia as Ukraine's Piedmont, University of Toronto Press, Toronto-Buffalo 2002.

Magocsi Paul Robert, The Scholar as Nation-Builder, or as Advisor and Advocate. Remarks Delivered by Paul Robert Magocsi (Chair of Ukrainian Studies, University of Toronto) for the Special Panel "Paul Robert Magocsi on the Scholar as a Nation-Builder" at the ASN 2007 World Convention, Columbia University, „Nationalities Papers” 36, 2008, 5, s. 881-892.

Magocsi Paul Robert, The Shaping of a National Identity. Subcarpathian Rus', 1848-1948, Harvard University Press, Cambridge Mass.-London 1978.

Magocsi Paul Robert, With Their Backs to the Mountains. A History of Carpathian Rus' and Carpatho-Rusyns, CEU Press, Budapest-New York 2015.

Michna Ewa, Łemkowie. Grupa etniczna czy naród?, Nomos, Kraków 1995.

Michna Ewa, Tożsamość Łemków u progu XXI wieku. Ciągłość i zmiana, „Studia Migracyjne - Przegląd Polonijny" 37, 2011, 4, s. 189-208.

Motyl Alexander, The Paradoxes of Paul Robert Magocsi. The case for Rusyns and the logical necessity for Ukrainians, „Nationalities Papers” 39, 2011, 1, s. 105-109. 
Myshanych Oleksa, Political Ruthenianism. A Ukrainian Problem, „The Ukrainian Quarterly" 55, 1997, 3 (http://www.lemko.org/rusyn/myshanych.html).

Nowak Jacek, Zaginiony świat? Nazywaja ich Łemkami, Universitas, Kraków 2000.

Plokhy Serhii, Between History and Nation. Paul Robert Magocsi and the Rewriting of Ukrainian History, „Nationalities Papers” 39, 2011, 1, s. 117-124.

Rethinking Ukrainian History, red. Ivan L. Rudnytsky, John-Paul Himka, Canadian Institute of Ukrainian Studies, Edmonton 1981.

Smith Anthony D., Nationalism and Modernism. A critical survey of recent theories of nations and nationalism, Routledge, London-New York 1998.

Subtelny Orest, Ukrajina. Istorija, Łybid', Kyjiw 1991.

Zamorski Krzysztof, Informator statystyczny do dziejów społeczno-gospodarczych Galicji. Ludność Galicji w latach 1857-1910, UJ, PTS, Kraków-Warszawa 1989.

Znaniecki Florian, Współczesne narody, PWN, Warszawa 1990.

Волощук Мирослав, „Русь” в Угорському Королівстві (ХІ - друга половина XIV cm.). Суспільно-політична роль, майнові стосункі, міграції, Lileja-NW, Ivano-Frankivs'k 2014.

Гийдел Ернест, Рутенія ӥber alles, „Україна Модерна” 2007, 12 (1), s. 191-217.

Грушевський Михайло, Iсторія України-Pуси, t. 1-11, Naukowa dumka, Kyjiw 1991.

Липи́нський В’ячесла́в (Вацлав), Україна на переломі. Замітки до історії державного будівництва в XVII-ім столітmю, Dniprosojuz, Kуjiw 1920.

Лисяк-Рудницький Іван, Драгоманов як політичний теоретик, w: idem, Icmoричні есе, t. 1, red. Франк Сисин, орrac. Ярослав Грицак, Osnowy, Kyjiw 1994, s. 299-348.

Лисяк-Рудницький Іван, Історичні есе, t. 1-2, red. Франк Сисин, орrac. Ярослав Грицак, Osnowy, Kyjiw 1994.

Лисяк-Рудницький Іван, Карпатська Україна. Народ у пошуках своеї ідентичності, w idem: Icторичні ece, t. 1, red. Франк Сисин, oprac. Ярослав Грицак, Osnowy, Kyjiw 1994, s. 451-470.

Томашівський Степан, Iсторія України. Старинні і середні віки, Ukrajinśkyj Wilnyj Uniwersytet, München 1948.

Biogram: Tomasz Stryjek, dr hab., profesor nadzwyczajny ISP PAN, wykładowca Collegium Civitas, historyk i politolog. Obszar zainteresowań naukowych: historiografia, ideologie narodowe, procesy narodotwórcze w XIX-XX w. oraz współczesna polityka pamięci w Europie Wschodniej i Południowo-Wschodniej; kontakt: tstryjek@wp.pl. 